\title{
Synergy Between Radionuclide and Infrasound Observations and Atmospheric Transport Modelling Simulations: Case of Bogoslof
}

\author{
J. Kuśmierczyk-Michulec, ${ }^{1}$ P. Bittner, ${ }^{1}$ P. Mialle, ${ }^{1}$ and M. Kalinowsir ${ }^{1}$
}

\begin{abstract}
To demonstrate a synergy between radionuclide (RN) and infrasound observations and Atmospheric Transport Modelling (ATM), the volcanic activity of Bogoslof in Alaska, USA, is used as an example. The study period covers 3 months of intense eruptive activity, from 19 December 2016 to 8 March 2017. During that period, the International Monitoring System (IMS) infrasound station located in Alaska, USA, recorded signals from three eruptive sequences. The second sequence was reported in the International Data Centre (IDC) Reviewed Event Bulletin (REB) with 3 infrasound stations: in Alaska, USA, in Kamchatka, Russian Federation and in Hawaii, USA. As reported by The Alaska Volcano Observatory (AVO), during each of these events ash plumes reaching the altitude of more than $10 \mathrm{~km}$ were observed for several consecutive days. These observations were used to identify the length of each eruptive episode. To demonstrate the influence of volcanic ash on the berillium-7 (Be-7) activity concentration values measured by two IMS RN stations in Alaska, the ATM was used. To monitor the arrival time of a volcanic ash plume at the IMS stations, a series of 14 days forward simulations released daily from Bogoslof during each of these events, was generated. Comparison of Be-7 daily surface values with the seasonal median for the period of 9 years (2009-2017), revealed that an influx of volcanic ash up to the tropopause (1.5-12 km) tends to locally increase surface Be-7 concentrations in area under the influence of subsiding ash plume. It is also demonstrated that with the arrival of volcanic ash at the surface level, the enrichment in radioactive particulates like uranium, thorium, and potassium was observed.
\end{abstract}

Keywords: CTBTO global monitoring system, atmospheric aerosols, beryllium-7, volcanic ash, infrasound observations, volcano, atmospheric transport modelling.

\section{Introduction}

The International Monitoring System (IMS) developed by the Comprehensive Nuclear-Test-Ban

The views expressed herein are those of the authors and not necessarily reflect the views of the CTBTO Preparatory Commission.

1 International Data Centre, Comprehensive Nuclear-TestBan Treaty Organization, PO Box 1200, 1400 Vienna, Austria. E-mail: jolanta.kusmierczyk-michulec@ctbto.org
Treaty Organization (CTBTO) is a global system of monitoring stations, using four complementary technologies: seismic, hydro-acoustic, infrasound and radionuclide (CTBTO 2018). The aim of the radionuclide stations $(\mathrm{RN})$ is a global monitoring of radioactive aerosols and radioactive noble gases supported by the atmospheric transport modeling (ATM) system. The aim of the infrasound stations is to detect signals from atmospheric nuclear explosions, however station detections also record signals from other sources both from anthropogenic activity and from natural sources such as earthquakes, thunderstorms, ocean swells, bolides or volcanic eruptions.

Explosive eruptions are seismo-acoustic sources, potentially generating large-amplitude acoustic and seismic waves. Eruption tremors or seismic tremors have typically limited propagation range and they are observed at maximum distance of a few tens of kilometers. For similar sized explosive eruptions, the infrasound signals produced are large and broadband and can be ducted efficiently overlong ranges (thousands of kilometers) in atmospheric waveguides. The IMS infrasound network designed to detect and locate powerful sources of infrasound, routinely detect signals originating from volcanic eruptions. In remote volcanic regions, infrasound is sometimes the only ground-based technology to record an explosive eruption and can therefore provide vital information to complement satellite data and constrain ash-release parameters for aviation safety (Johnson and Ripepe 2011; Matoza et al. 2019). After propagating in the atmosphere, volcanic ash injected in the atmosphere during eruption sequences can potentially be observed at the RN stations. This study will focus on the volcanic activity of Bogoslof (53.93 N, 
$168.03 \mathrm{~W}$ ), that occurred between 19 December 2016 and 8 March 2017, to demonstrate the challenge of synergy between $\mathrm{RN}$ and infrasound observations linked by ATM simulations.

Bogoslof is entirely within the Bering Sea, about $40 \mathrm{~km}$ North of the main Aleutian arc, Alaska. It belongs to a submarine volcano type with an elevation of $150 \mathrm{~m}$ (Global Volcanism Program 2013). The closest RN station USP71 $(55.3 \mathrm{~N}, 160.5 \mathrm{~W})$ is in the distance of about $500 \mathrm{~km}$, and the closest infrasound station, I53US $(64.8 \mathrm{~N}, 146.9 \mathrm{~W})$, also co-located with RN station USP76 $(64.4 \mathrm{~N}$, $147.1 \mathrm{~W}$ ), is in the distance of about $1600 \mathrm{~km}$ (see Fig. 1). Bogoslof is composed almost entirely of igneous rocks of Cenozoic age, including mainly hornblende andesite and basalt (Byers 1959). Chemical analysis indicates that $\mathrm{SiO}_{2}$ is the main element; it accounts for approximately 52\% of hornblende basalt. Volcanic activity dates back to the seventeenth century (Byers 1959). The history of Bogoslof between 1768 and 1900 is described by Merriam
(1902), a member of the Harriman Alaska Expedition, organized in 1899 i.e. 32 years after the United States purchased Alaska (Byers 1959). Since 1988 Bogoslof's activity is monitored by The Alaska Volcano Observatory (AVO), a joint program of the United States Geological Survey (USGS), the Geophysical Institute of the University of Alaska Fairbanks (UAF-GI), and the State of Alaska Division of Geological and Geophysical Surveys (ADGGS).

The most recent eruptions began in December 2016 based on results obtained from multi-disciplinary approach to rapidly detect explosive eruptions in Alaska's Aleutian arc using local to regional monitoring means (Coombs et al. 2018). According to information reported by AVO and the Anchorage Volcanic Ash Advisory Center (VAAC), ash plumes associated with numerous explosions between December 2016 and March 2017 rose to over $10 \mathrm{~km}$ altitude. During the eruptive sequence of Bogoslof, IMS infrasound station I53US in Alaska routinely

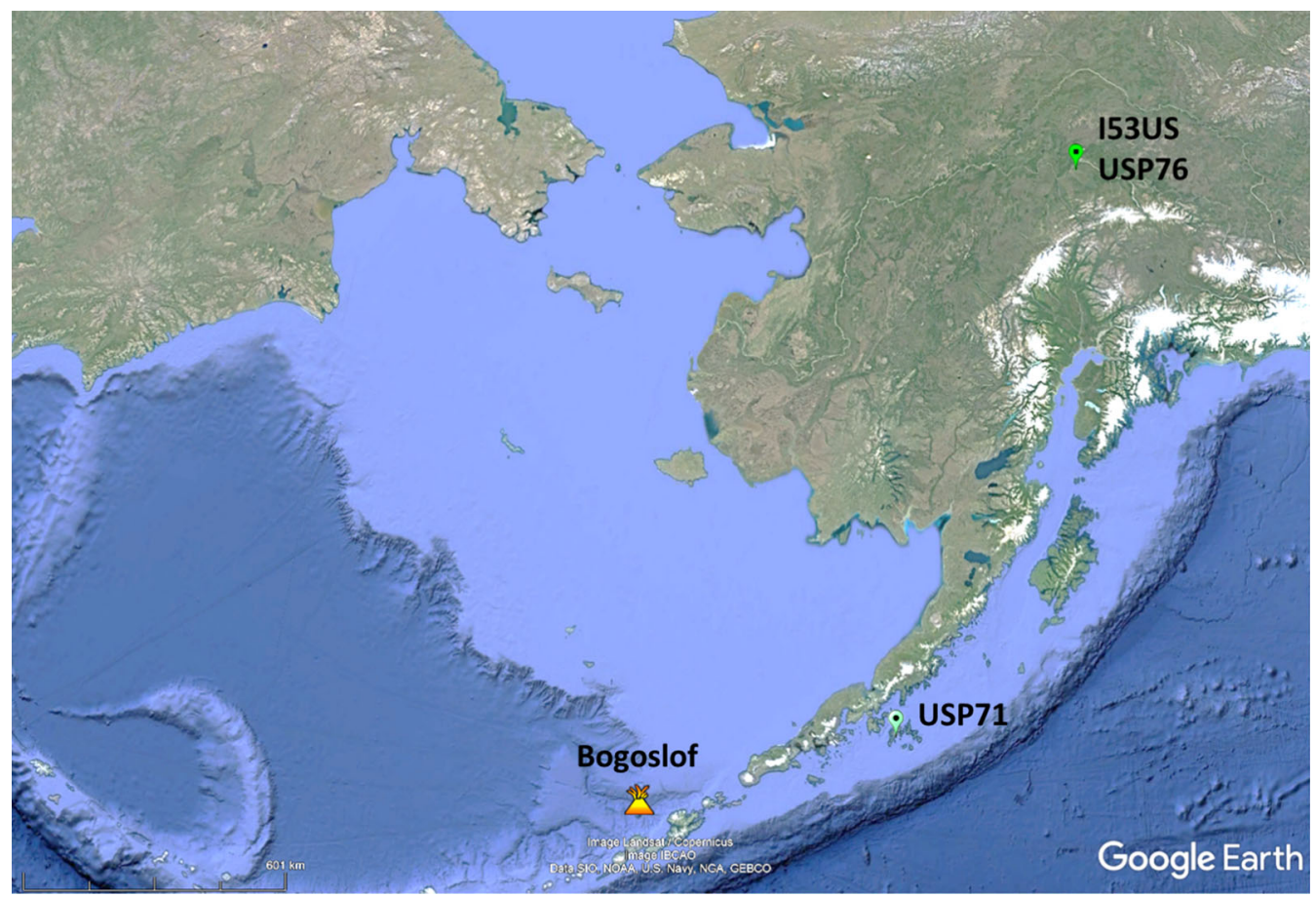

Figure 1

Map showing the location of Bogoslof $(53.93 \mathrm{~N}, 168.03 \mathrm{~W})$ and the selected IMS stations. RN stations: USP71 (55.3 N, $160.5 \mathrm{~W}$, elevation $60 \mathrm{~m}$ ) in Sand Point (Alaska), USP76 (64.4 N, $147.1 \mathrm{~W}$, elevation $150 \mathrm{~m}$ ) in Salchaket (Alaska) and the infrasound station: I53US (64.8 N, $146.9 \mathrm{~W}$ )-co-located with USP76 
registered signals originating from Bogoslof. It should be noted that the volcanic activity continued until January 2018, characterized by various level of eruptive intensity having a large impact on the size and shape of the volcano and the corresponding island body. Due to this varying eruptive intensities, several IMS infrasound station potentially recorded infrasound waves from Bogoslof, as described in details in the background section. In the second half of March 2017, another volcano in Alaska, Cleveland $(52.83 \mathrm{~N}, 169.94 \mathrm{~W})$, located about $180 \mathrm{~km}$ from Bogoslof became active. To focus solely on Bogoslof volcanic activity and avoid contamination from other radionuclide sources, the study period considered in this paper was limited to 3 months, from 19 December 2016 to 8 March 2017.

Volcanic ash is formed during explosive volcanic eruptions when dissolved gases in magma expand and escape violently into the atmosphere. Early studies of the radioactivity released from volcanos were done on lava rocks with the intention to derive information about crystallization, fractionation and other dynamical processes inside of the volcano (Oversby and Gast 1968). Studies on the radioactivity content of volcanic ashes were typically conducted on ash deposits to determine the radiation hazard for the local population (Rafiza et al. 2013). The radioactivity content of volcano ash plumes was typically measured on degassing samples taken directly from the vicinity of the volcano for example to infer information about the internal processes like magmatic degassing dynamics from disequilibria of the isotopic ratios (Gauthier et al. 2000; Lambert et al. 1985; Terray et al. 2018). In case of Bogoslof, two closest RN stations enable a continuous observation of aerosol samples of radionuclides. Any sample of volcanic ash that contains radioisotope above detection threshold is included in the Reviewed Radionuclide Report (RRR), published by the IDC. Such a report includes manually verified results from automated analysis of a particulate or gas samples, as well may also contain sample analysis results from certified laboratories.

$\mathrm{RN}$ stations monitor various radioactive aerosols but beryllium-7 (Be-7) is one of two natural radionuclides measured on a daily basis. Be-7 ( $\mathrm{T}_{1 / 2}$ $=53.3$ days), originates from spallation of nitrogen and oxygen nuclei by energetic particles associated with cosmic radiation entering the atmosphere (e.g. Benioff 1956; Usoskin and Kovaltsov 2008). The amount of Be-7 that reaches the surface depends on the production rate, which is a function of latitude, altitude and solar activity (e.g. Masarik and Beer 1999). Approximately $2 / 3$ of $\mathrm{Be}-7$ is produced in the stratosphere and the remaining $1 / 3$ in the upper part of the troposphere (Lal and Peters, 1967; Zanis et al. 2003). Be-7 attaches predominantly to aerosol particles in the submicron size range (e.g. Ioannidou et al. 2005) with an activity mean diameter of typically $0.5-0.7 \mu \mathrm{m}$ (e.g. Lange 1994) and is removed from the atmosphere by dry and wet depositions (e.g. Kuśmierczyk-Michulec et al. 2015). Be-7 is one of the most important environmental radionuclides related to large-scale atmospheric circulation dynamics (Terzi and Kalinowski 2017), often used to aid in identifying a stratosphere-to-troposphere transport (STT) signature (e.g. D'Amours et al. 2013; Brattich et al. 2017).

Kuśmierczyk-Michulec and Bourgouin (2018) demonstrated that an influx of aerosol particles e.g. dust in the troposphere $(3-10 \mathrm{~km})$ tends to locally increase surface $\mathrm{Be}-7$ concentrations in area under the influence of subsiding dust plume. This study will demonstrate a similar mechanism for volcanic ash as observed at the RN stations: USP71 and USP76, during the series of volcanic eruptions of Alaska's Bogoslof volcano registered between December 2016 and March 2017 by up to three IMS infrasound stations. To monitor the arrival time of volcanic ash plumes at RN stations, the ATM results were used. Modelling of the dispersion of volcanic ash plume is subject to large uncertainties. To realistically forecast ash concentrations the proper knowledge of model input parameters, such as volcanic plume height, mass eruption rate, particle size distribution and duration are essential. However, this type of data is not always available. Mastin et al. (2009) present a multidisciplinary effort to assign realistic source parameters to models of volcanic ash-cloud transport, which can be used in the event of an eruption, when no observational constraints on these parameters are available. This paper presents an alternative approach. The synergy of RN and infrasound technologies jointly with ATM allows overcoming 
limitations related to a single technology and provides a more complete picture of the Bogoslof eruptive sequence and its consequences with propagation of gases in the atmosphere.

\section{Background Data}

\subsection{Be-7 and Other Radioactive Particles}

The measurements of Be-7 activity concentrations is a by-product of the IMS radionuclide stations. The main purpose is to detect anthropogenic radionuclides that may indicate a nuclear test. The normal observations contain natural radionuclides and $\mathrm{Be}-7$ is routinely observed. Air sampling is conducted using a high-volume air filtration unit operated on a routine methodology from a network of RN stations. At each station, $500-1000 \mathrm{~m}^{3} / \mathrm{h}$ of air is continuously filtered by using various types of filter papers. The particulate radionuclides collection efficiency is good; the collectors are designed to catch more than $80 \%$ of particles with diameter larger than $0.2 \mu \mathrm{m}$. Each sample is collected during a $24-\mathrm{h}$ period. The activity concentration of $\mathrm{Be}-7$ and other aerosol-bound radionuclides is measured with high-resolution germanium detectors (Schulze et al. 2000; Medici 2001). The minimum detectable activity concentration (MDC) of Be-7 varies for different stations, but is on average about $5-30 \mu \mathrm{Bq} / \mathrm{m}^{3}$. It should be mentioned that according to the standard procedure a 24-h decay period is observed after sampling before analyzing samples. This period of time allows reducing all short-lived radionuclides that decayed in that time, thus improving the detection limit. All activities of air sampling and gamma spectroscopy are conducted by local station operators. The spectral pulse height data are sent to the IDC immediately after acquisition stop. The IDC processes the data, immediately generates an Automated Radionculide Report (ARR) followed by interactive analyst review and the release of the RRR. For each sample this report is available and lists all detected radioisotopes with their concentrations.

In this study, data collected during 9 years period, from 2009 to 2017 by two IMS radionuclide stations USP71 and USP76 (see Fig. 1) were used. All information about the radioactive isotopes present in the collected aerosol particles comes from the IDC report RRR. If any volcanic ash is collected that contains radioisotope above detection limit, these are included in the RRR.

\subsection{Recording by IMS Stations of Infrasound Signals Generated by Volcanic Eruption}

Research in the field of infrasound was revived by monitoring the Earth atmosphere for possible nuclear explosion with the establishment of the CTBT verification regime. Infrasound technology research evolved beyond the verification regime with the emergence of scientific and civil applications, one of them being the monitoring of active volcanoes (Fee and Matoza 2013). Weather conditions and in particular cloud coverage may limit observations of volcanic eruptions with traditional observation technique, such as with satellite sensing. Other observational means may also be affected when active volcanoes are located in remote locations or due to the intensity of the eruptive sequence that prevent installation of equipment in the vicinity of the volcano, as it is in case of Bogoslof. Examining volcano-generated infrasound, which can propagate over large distances through the atmosphere, may be a useful and complementary mean for detecting volcanic activity.

The IMS infrasound network is composed of 60 globally distributed stations, at the time of the Bogoslof eruptive sequence over $80 \%$ of the stations were certified and sending data in real time to the IDC. Each of these stations is composed of an array of infrasound measurement systems capable of recording micropressure changes produced by the propagation of infrasonic waves. Stations are separated by a couple of thousands of kilometres and may be affected by local environmental conditions, which drop signal to noise ratio to low levels. To detect infrasound signals it is assumed that wind generated noise is uncorrelated across the array. The IDC applies Progressive Multi Channel Correlation (PMCC) (Mialle et al. 2019) algorithm to detect infrasound signal and estimate related wave parameter such as frequency content, direction of arrival or apparent trace velocity. The IMS infrasound network 
is designed to detect and locate powerful sources of infrasound, which are often detected at distances of thousands of kilometres by a small number of stations.

Acoustic waves are produced by shallow subsurface and subaerial processes, including explosive eruptions, shallow degassing, surface flow, and mass wasting (Matoza et al. 2019). Explosive eruptions are seismo-acoustic phenomena, generating large-amplitude acoustic waves. Infrasound waves generated by large volcanic eruptions can propagate at large distance, hundreds to thousands of kilometres under favourable atmospheric propagation conditions. Volcanic activity may last for several days and be characterized as a long duration signal of fluctuating amplitude or a sequence of short duration events. The dominant frequency and amplitude of infrasonic waves from volcanic explosions depends on the size of the explosion and the distance from the source. In case of investigated events related to Bogoslof eruptions, three intervals of activity were observed, each one lasting less than an hour. I53US in Alaska (see map in Fig. 1) and I44RU in Kamchatka are the closest IMS infrasound stations from Bogoslof. Both are located more than $1500 \mathrm{~km}$ away from the volcano, with I53US located to the east and I44RU to the west.

The propagation and the speed of infrasonic waves in the air are strongly influenced by the thermal properties of the atmosphere and the horizontal winds between the ground and the middle atmosphere (Brown et al. 2002). The atmosphere is a strongly heterogeneous medium in constant evolution and with some significant variations related to the latitude or to seasonal and diurnal effect.

Since the activity of this volcano was investigated in winter conditions in the Northern Hemisphere where the Bogoslof volcano is located, the prevailing direction for the stratospheric winds made observations at I53US more likely. It takes about 90 min for infrasound waves to reach I53US from events located at Bogoslof, assuming an isotropic propagation with a celerity of $300 \mathrm{~m} / \mathrm{s}$ (Brown et al. 2002). The theoretical direction of arrival of infrasound at I53US is $232^{\circ}$.

\subsubsection{Event 1: 19 December 2016 at 15:30}

On 19 December 2016, a long lasting broadband signal was observed in I53US recordings. The signal was automatically picked up by IDC automatic processing system for infrasound technology, which uses the PMCC algorithm. Bogoslof volcano eruption was the most likely origin of this signal, however the lack of corroborating information from IMS seismic, hydro-acoustic, infrasound stations could not permit to create an event in IDC products. Figure 2 displays the signal recorded by I53US and the related information obtained by PMCC (the results have been reprocessed offline to enhance signal attribute extraction).

\subsubsection{Event 2: 20 January 2017 at 22:30}

On 20 January 2017, infrasound signals recorded at 3 IMS infrasound station located in Kamchatka, Russian Federation (I44RU), Alaska, USA (I53US) and Hawaii, USA (I59US) were associated to form an event that was included in the Reviewed Event Bulletin (REB) of the IDC. The event locates in the vicinity of Bogoslof volcano. Figure 3 displays the signal and PMCC results for I53US station and a map of the event with back-azimuth path from the detecting station is added.

\subsubsection{Event 3: 17 February 2017 at 19:30}

On 17 February 2017, I53US once again recorded infrasound waves emanating from the Bogoslof eruption. It should be noted that infrasound waves likely originating from Bogoslof volcano eruption have been recorded throughout the eruptive sequence, however the examples provided have been chosen to illustrate the variability of the recordings over time and to complement the radionuclide detections and ATM analysis provided in Sect. 4. Figure 4 illustrates the signals recorded at I53US station and the related detection from PMCC algorithm.

\subsection{Observation of Volcanic Ash Plume by AVO}

Since there is no ground-based monitoring equipment on Bogoslof, the monitoring by the Alaska 


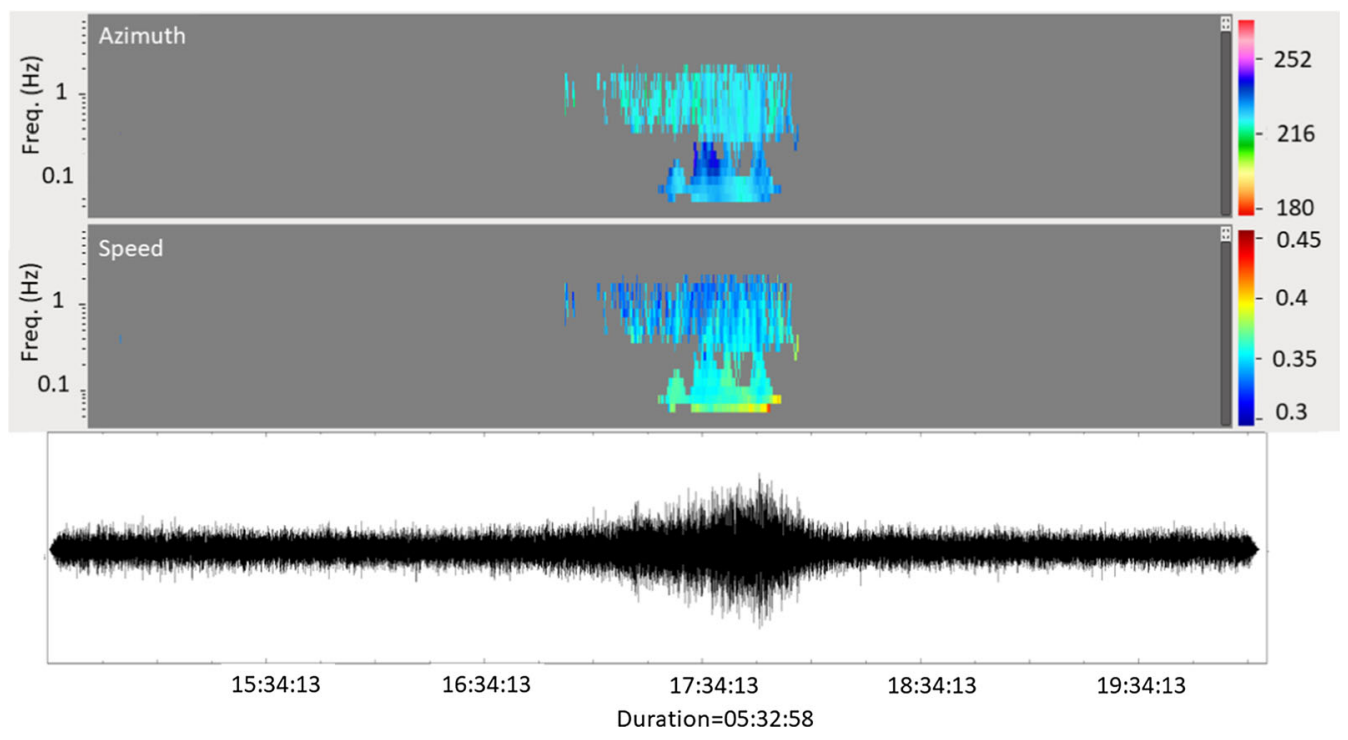

Figure 2

Event 1, Bogoslof volcanic eruption registered by I53US on 2016/12/19 between around 17:00 and 18:00 UTC. The top two panels display the DTK-PMCC (specialized software for station processing of array data based on PMCC method) results in back azimuth $\left(226^{\circ}\right)$ and trace velocity $(0.35 \mathrm{~km} / \mathrm{s})$ and the bottom panel exhibits the beamformed waveform for the displayed detections (frequency band $0.5-2 \mathrm{~Hz}$ ). Note that detections not related to the Bogoslof eruption are masked

Volcano Observatory (AVO) is accomplished using satellite images, information from the Worldwide Lightning Location Network pertaining to volcaniccloud lightning (Global Volcanism Program 2017). The infrasound network includes seismic and infrasound instruments, located on neighboring Umnak (100 km SW), Unalaska Islands (85 km SE), Sand Point (500 km E) on Popof Island, and on the Alaska mainland in Dillingham (825 km NE). The additional sources of information are observations from ships and airplanes.

As reported by AVO, in the period between 19 December 2016 and 8 March 2017, ash plumes reaching the altitude of more than $10 \mathrm{~km}$ were observed for several consecutive days. Comparison of this type of observation with earlier described infrasound recordings by IMS station I53US, allowed to estimate the length of these three episodes: the first one, from 19 December 2016 to 31 December 2016, the second one, from 20 January 2017 to 3 February 2017 and the third one, from 17 February 2017 to 8 March 2017.

\subsection{Meteorological Observations}

Meteorological data was collected by meteorological equipment placed at the sampling stations and recorded every $10 \mathrm{~min}$. The recorded parameters include: air temperature, wind speed, wind direction, relative air humidity, atmospheric pressure and rainfall. Data from the meteorological station were averaged over $24 \mathrm{~h}$. When these data were not available, the meteorological data from the external sources were used: https://www.timeanddate.com/ weather/@5871861. This paper will also make use of operational 12-h (0000 and 1200 UTC) soundings from the Fairbanks (PAFA, 70261) and Cold Bay (PACD, 70216) available via http://weather.uwyo. edu/upperair/sounding.html.

\section{ATM Methodology}

The subsequent sections will provide a brief description of the Atmospheric Transport Modelling System used at CTBTO for the purpose of global and real time monitoring (Sect. 3.1) and assumptions 

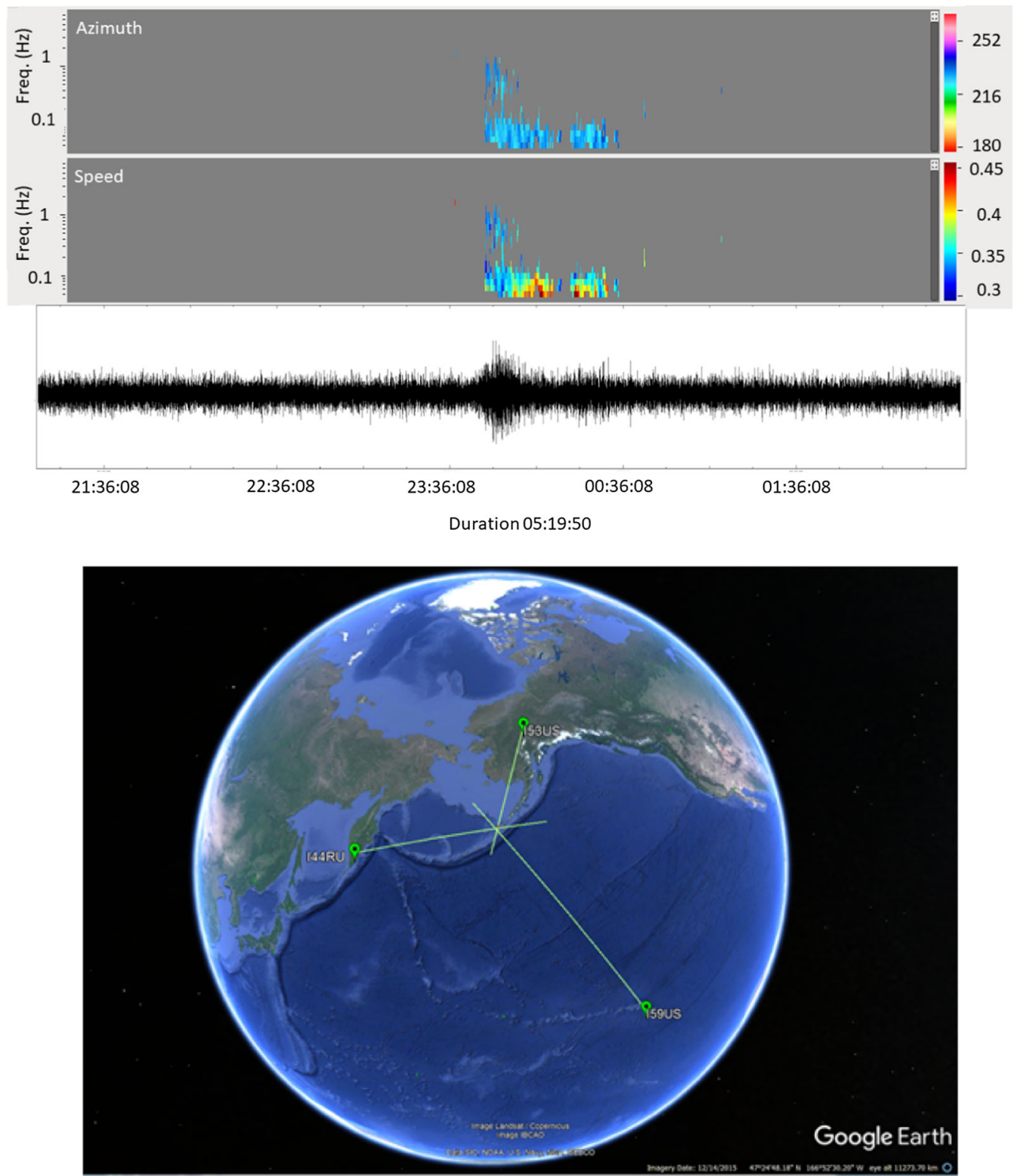

Figure 3

Event 2, Top figure: Bogoslof volcanic eruption registered by I53US on 2017/01/20 between around 23:45 to 2017/01/21 around 00:45 UTC. The top two panels display the DTK-PMCC results in back azimuth $\left(232^{\circ}\right)$ and trace velocity $(0.35 \mathrm{~km} / \mathrm{s})$ and the bottom panel exhibits the beamformed waveform for the displayed detections (frequency band $0.4-1.8 \mathrm{~Hz}$ ). Note that detections not related to the Bogoslof eruption are masked. Bottom figure: Map with the REB location superimposed with back azimuth (green lines) from 3 IMS infrasound station

related to modelling of volcanic ash plume (Sect. 3.2).

\subsection{Atmospheric Transport Modelling (ATM)}

The Atmospheric Transport Modelling (ATM) system used at CTBTO is based on the Lagrangian particle dispersion model FLEXPART, which is an open-source code, released under the GNU General Public License and maintained by a scientific community (http://flexpart.eu). FLEXPART can operate in forward as well as backward mode. In forward mode the dispersion of tracers from their sources is simulated forward in time i.e. particles are released 


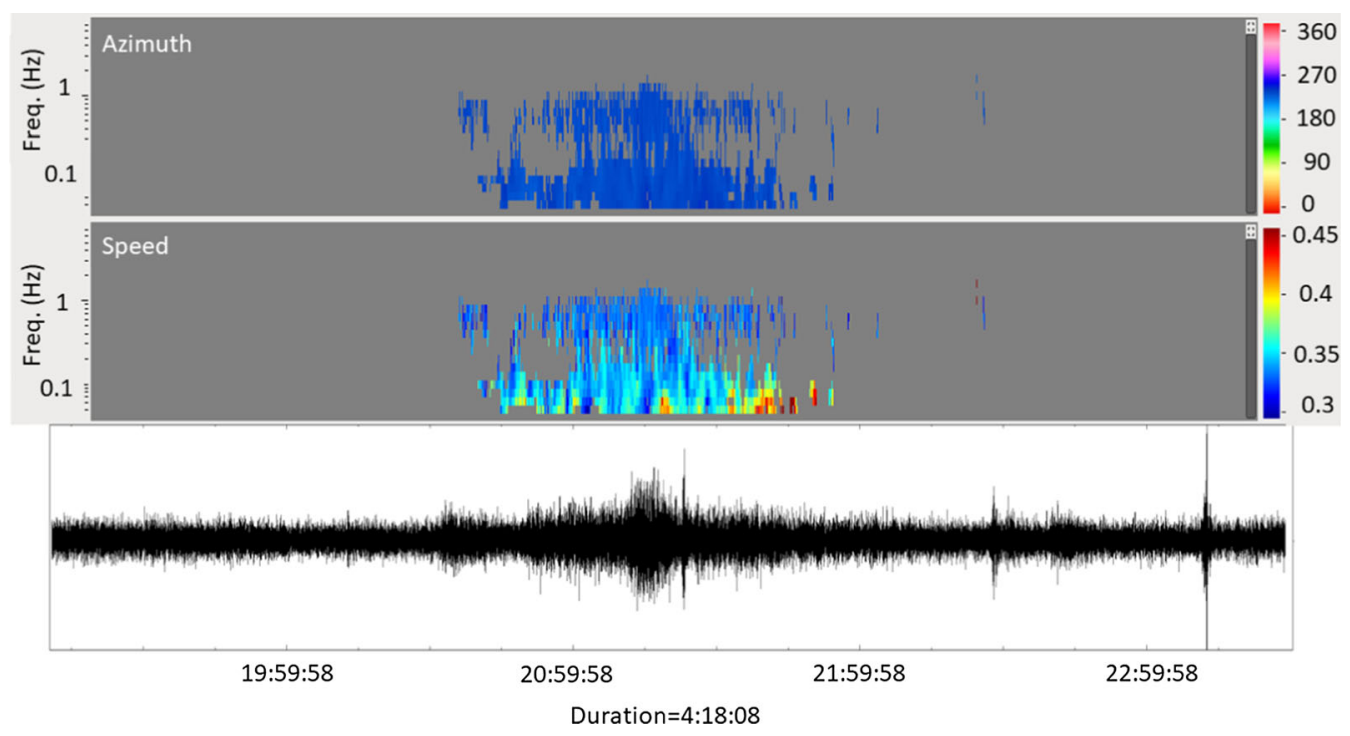

Figure 4

Event 3, Bogoslof volcanic eruption registered by I53US on 2017/02/17 between around 20:30 and 22:00 UTC. The top two panels display the DTK-PMCC results in back azimuth $\left(230^{\circ}\right)$ and trace velocity $(0.34 \mathrm{~km} / \mathrm{s})$ and bottom panel exhibits the beamformed waveform for the displayed detections (frequency band $0.04-1.4 \mathrm{~Hz}$ ). Note that detections not related to the Bogoslof eruption are masked

from one or a number of sources and concentrations are determined downwind on a grid. In the backward mode the potential source contributions for given receptors are determined based on simulations backward in time, i.e. particles are released from a receptor location (e.g., a measurement site) and a four-dimensional (3 space dimensions plus time) response function (sensitivity) to emission input is calculated (Stohl et al. 2005).

For the purpose of CTBTO, i.e. the global and real time monitoring of radionuclides (RNs), the simplified source-receptor matrix concept was used (Wotawa et al. 2003). Assuming that AC is the activity concentration of one specific $\mathrm{RN}$ measured within one sample taken during $12 \mathrm{~h}$ or $24 \mathrm{~h}$ at one single IMS RN station, then $\mathrm{AC}$ in $\left[\mathrm{Bq} / \mathrm{m}^{3}\right]$ can be expressed as (Wotawa et al. 2003):

$$
A C=M_{i j n} S_{i j n},
$$

where $\mathrm{S}$ in $[\mathrm{Bq}]$ is a spatio-temporal source field, and $\mathrm{M}$ in $\left[\mathrm{m}^{-3}\right]$ is a corresponding source-receptor sensitivity (SRS) field at a discrete location (i,j) and a time interval $n$. The inverse elements of $M$ have the dimension of a volume, which can be interpreted as the dilution volume; under the assumption of evenly dispersed source, they would give the concentration AC. Equation (1) is valid for a single point source. In case of a multiple source scenario, it has to be modified:

$$
A C=\sum_{i, j, n} M_{i j n} S_{i j n}
$$

For the purpose of this study FLEXPART version 9.3.2, in a forward mode was used.

In the simulations the analysed wind data provided by the European Centre for Medium-Range Weather Forecasts (ECMWF) were used with the spatial resolution of $0.5^{\circ}$ (or $1^{\circ}$ in case the $0.5^{\circ}$ data were not available). The output was for $0.5^{\circ}$.

\subsection{Modelling of Volcanic Ash Plume}

To monitor the arrival time of volcanic ash plumes at RN stations, the ATM results were used. Since the maximum observed plume altitude at Bogoslof was approximately $12 \mathrm{~km}$, this value was assumed in the simulations. Chemical analysis indicates that $\mathrm{SiO}_{2}$ is the main element; it accounts for approximately $52 \%$ of hornblende basalt. Therefore, $\mathrm{SiO}_{2}$ was assumed as a proxy of volcanic ash in this 
case. On the list of other elements are also: $\mathrm{Al}_{2} \mathrm{O}_{3}$, $\mathrm{Fe}_{2} \mathrm{O}_{3}, \mathrm{FeO}, \mathrm{CaO}, \mathrm{Na}_{2} \mathrm{O}$ and $\mathrm{K}_{2} \mathrm{O}$ (Byers 1959).

For each event, identified in Sect. 2.3, a series of 14-day forward simulations was conducted daily, with a release point at Bogoslof. In the next step, for two IMS stations i.e. USP71 and USP76, the arrival time of a plume was monitored, and for a given station, the volcanic ash concentration was estimated by summing over all the contributions from the individual FLEXPART runs covering the given period. This summing approach mimics the collection time of radioactive particulates like Be-7 by IMS stations.

The outputs were generated for 9 layers: $0-150$, 150-500, 500-1000, 1000-1500, 1500-2000, 2000-3000, 3000-4000, 4000-6000, and 6000-12000 m.

\section{Results}

\subsection{Winter Atmospheric Boundary Layer (ABL) of Interior and Southwest Alaska}

It is well documented that as a result of extreme meteorological conditions, the winter atmospheric boundary layer (ABL) of interior Alaska is very complex (e.g. Mayfield and Fochesatto 2013; Malingowski et al. 2014). The winter ABL is characterized by low-level locally controlled surface-based inversions (SBI) and upper-level synoptically controlled elevated inversions (EI) layers (Mayfield and Fochesatto 2013). These SBI layers very effectively accumulate pollutants in urbanized areas. Based on the statistical analysis of radiosonde observation data from the Fairbanks National Weather Service station, from January 2000 to December 2009, Mayfield and Fochesatto (2013) calculated that the mean SBI height was $377 \mathrm{~m}$. Furthermore, the authors found that an SBI occurred in combination with one, two, three, or four simultaneous EIs at altitude between 1200 and $3200 \mathrm{~m}$. The meteorological conditions initiating the formation of EI above the more persistent SBI at the mesosynoptic level include the occurrence of warm-air advection or the presence of an anticyclone in the northern regions, which promote subsidence inversions aloft under generally clear sky conditions (Mayfield and Fochesatto 2013).

The radiosonde measurements available from University of Wyoming (http://weather.uwyo.edu) for two locations: Fairbanks (IMS station USP76) and Cold Bay were used to analyze the ABL structure during the period considered in this study i.e. 19 December 2016-8 March 2017. It should be noted that for Fairbanks we could recognize the similar features in the winter ABL, as reported by Mayfield and Fochesatto (2013). Cold Bay $(55.20 \mathrm{~N}$, $-162.725 \mathrm{~W}$ ) is located between the IMS station USP71 (about $131 \mathrm{~km}$ ) and Bogoslof Volcano (about $380 \mathrm{~km}$ ), and is used as the representative point of Southwest Alaska.

\subsection{Arrival Time of the Ash Plume at USP71 and USP76 and Comparison to the Infrasound Signal}

In the ideal case, even if the event took place about $1500 \mathrm{~km}$ away, the infrasound station may receive the signal associated with the volcanic eruption within $90 \mathrm{~min}$. This is because the speed of sound in air is about $343 \mathrm{~m}$ per second. The air masses travel much slower, and their trajectories may be very complex, therefore their arrival time even for the same distance may differ. The colocation of both stations I53US and USP76 gives an opportunity for direct comparison. The station USP71 is the intermediate point on the way between Bogoslof and USP76.

Figure $5 \mathrm{a}-\mathrm{f}$ show volcanic ash plume associated with Bogoslof eruptions for release occurring at the time of the infrasound event above two radionuclide stations USP71 and USP76 and for the three eruptive sequences discussed in this study. $\mathrm{T}_{0}$ marks the beginning of each eruptive event, i.e. 19 December 2016 (Fig. 5a, b), 20 January 2017 (Fig. 5c, d) and 17 February 2017 (Fig. 5e, f), that were inferred from infrasound observations. It is interesting to note that the influx of ash plume varies with altitude and that the arrival at the surface is preceded by an influx of volcanic ash at higher levels (above $2 \mathrm{~km}$ ). Comparison of scales displaying the relative amount of volcanic ash reveals that on average on the path 
A

USP71, $T_{0}=19$ December 2016

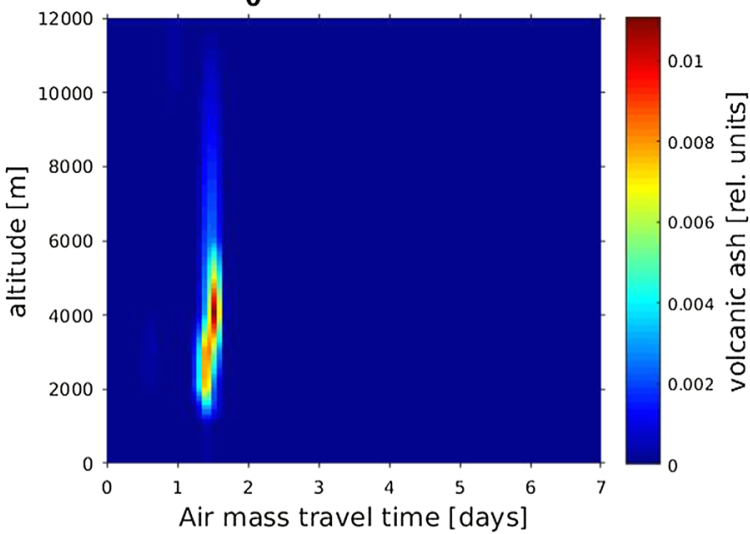

C
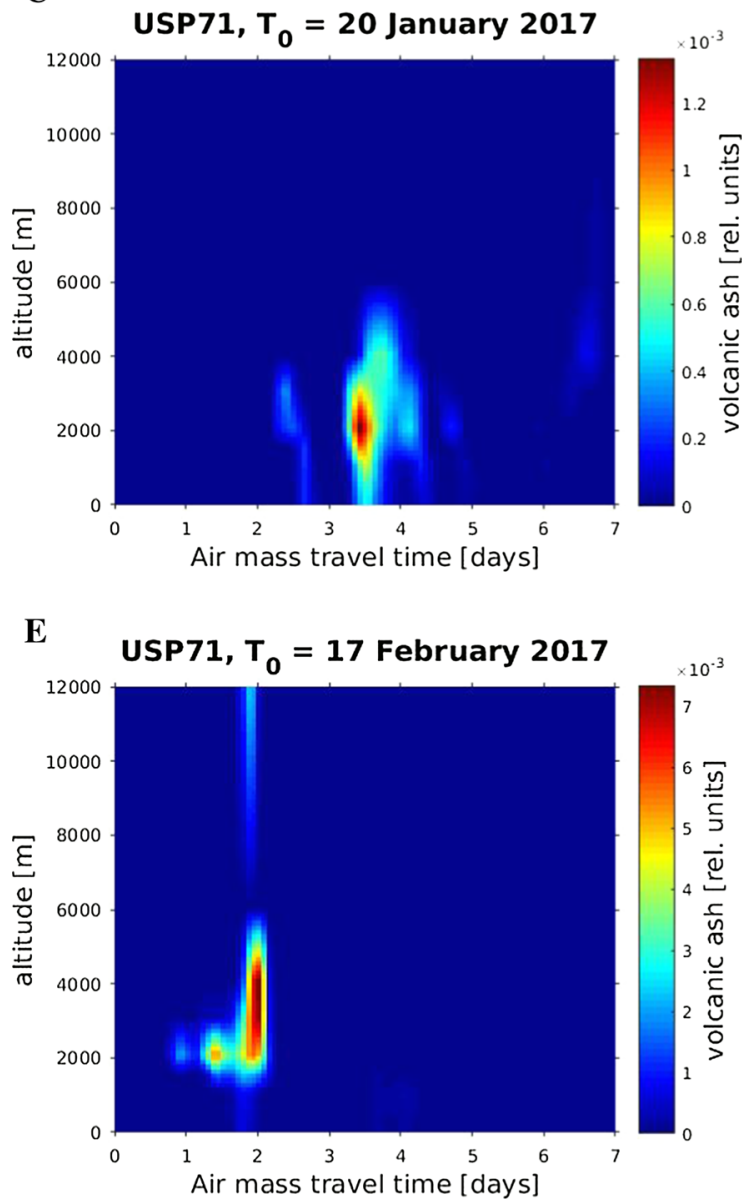

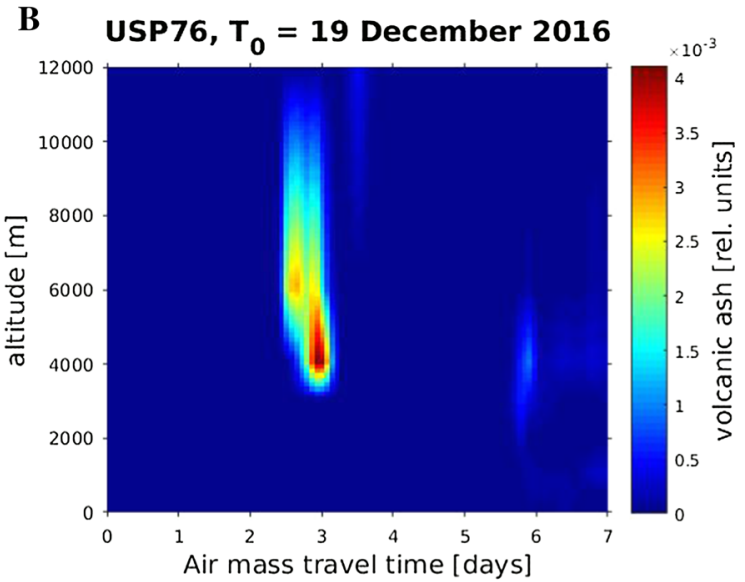

D
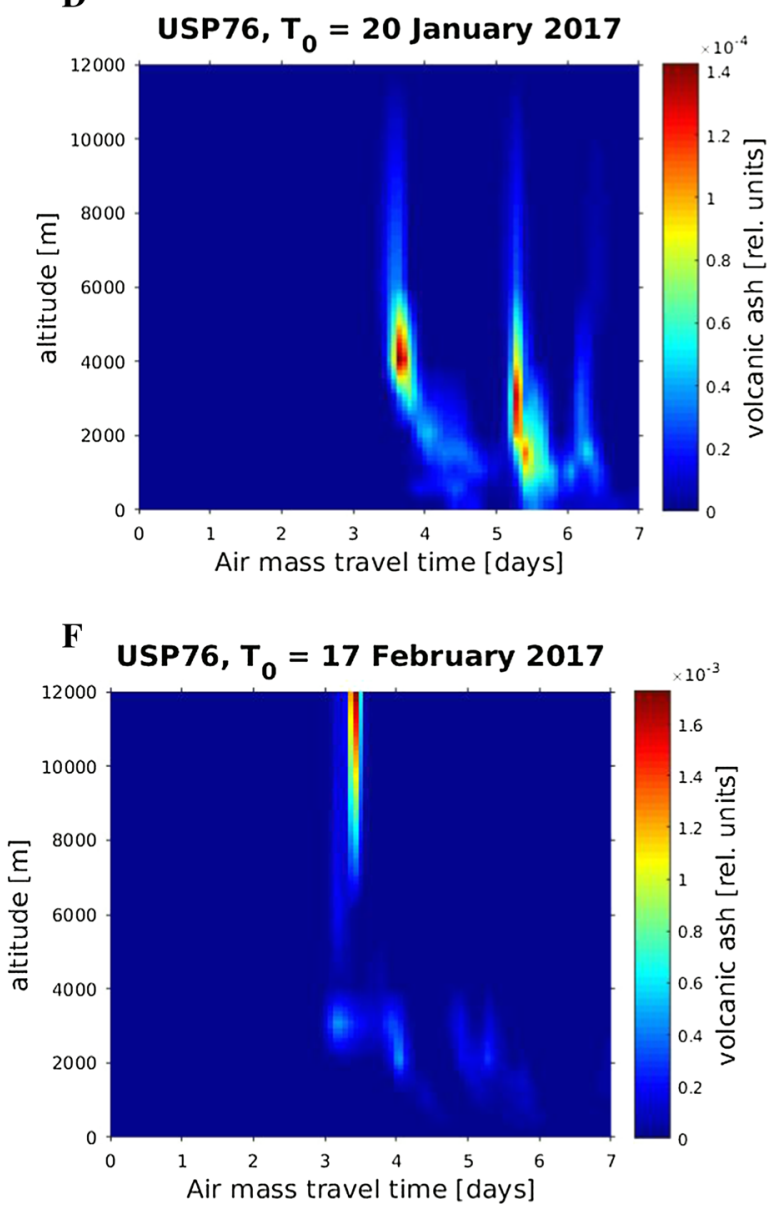

Figure 5

a-f Sequence of snapshots showing the evolution of the volcanic ash plume associated with Bogoslof eruptions and released at the time of the infrasound event. $T_{0}$ marks the beginning of each eruptive event, i.e. 19 December 2016 (a, b), 20 January 2017 (c, d) and 17 February 2017 $(\mathbf{e}, \mathbf{f})$, that were inferred from infrasound observations. The plume passage over two radionuclide stations USP71 and USP76 is monitored during 7 consecutive days counting from the release $\mathrm{T}_{0}$. For comparison, the infrasound signal arrives at I53US, collocated with USP76, after approximately $90 \mathrm{~min}$ from the release 
between both stations the amount of ash decreases about one order of magnitude.

During the first episode that started on 19 December 2016 at 15:30, the ash plume reached USP71 (i.e. appeared at the surface level) only after $30 \mathrm{~h}$ (1.25 day) and USP76 after $135 \mathrm{~h}$ (5.625 days) as demonstrated in Fig. 5a, b. During the second episode that started on 20 January 2017 at 22:30, the travel time to USP71 was much longer. The first plume arrived at the surface level after $60 \mathrm{~h}$ (i.e. 2.5 days) but the central (main) plume after 3.5 days from the release (Fig. 5c). Figure 5d demonstrates that the ash plume at USP76 was observed twice with a time interval of 1 day. During the third episode that started on 17 February at 19:30, the ash plume needed only 1.5 days to reach USP71, and 4.625 days to reach USP76.

Figure $6 \mathrm{a}, \mathrm{b}$ reveals why during the second episode the arrival time was much longer than during two other episodes. It was related to the air mass trajectories. The plume released on 20 January instead on going directly to USP71, moved to the south (to the lower latitudes) along the west coast of Canada and USA (Fig. 6a), and only 2 days later, the situation has changed and part of the plume veered north-eastward and moved in the direction of the Gulf of Alaska. Figure 6a shows a snapshot of this situation at the surface level $(0-150 \mathrm{~m}), 4$ days after the release. The main plume is over western coast of USA, but the second part of the plume is arriving at USP71 and USP76, at the same time. In case of upper-level circulations (between 4 and $6 \mathrm{~km}$ ), the plume arrived at USP76 and USP71 much faster (Fig. 6b). According to NOAA (2017), a strong westerly flow dominated the upper-level circulation across the contiguous United States during January 2017. It could also explain the air mass trajectories displayed in Fig. 6 b.

\subsection{Radioactive Elements Present in the Volcanic Ash}

Figures $7 \mathrm{a}-\mathrm{c}$ and $8 \mathrm{a}-\mathrm{c}$ display, which radioactive particulates were measured at both IMS stations at the surface level during all 3 episodes. In each case the beginning of observations is marked by the arrival of the plume at the surface, as indicated by the ATM simulations. Especially interesting is the first episode because of unusual measurements of potassium K-42 $(12.36 \mathrm{H}$ half-life) at USP71, in the amount of 88 $\mu \mathrm{Bq} / \mathrm{m}^{3}$, the day after the release from Bogoslof. The measurements of K-42 at USP71 were confirmed by certified laboratory. As the ATM simulations indicate, the arrival of volcanic ash at the surface level continued during the next days. The maximum amount of volcanic ash was expected to be on 25 December. It coincides with the measurements of Protactinium Pa-234 $\mathrm{m}$ which occurs in the decay chain of uranium U-238, and is not regularly measured at this station.

The volcanic plume released on 19 December arrives at USP76 at the surface level 5 days later, i.e. on 24 December. It coincides with higher than normal measurements of sodium Na-24. In addition also other radioactive particles were measured like $\mathrm{Bi}$ $214, \mathrm{~Pb}-214$, both belonging to uranium series. A dashed line in Fig. 8a indicates the arrival of the ash plume at the surface. The extended time series to few days before the event illustrates pre-eruption levels for the studied radionuclides.

It is interesting to note that at USP71 during all 3 episodes similar radioactive particles were measured like Th-234, K-40, Na-24 or U-235. In case of USP76, the presence of Th-234 seems to be replaced by his decay products (daughters) $\mathrm{Bi}-214$ and $\mathrm{Pb}-214$.

The presence of these radioactive elements can be related to the Bogoslof eruption. It is known that when magma rises towards the surface it is filled with an assortment of elements; among them are uranium, thorium, and potassium.

\subsection{Monthly Distribution of Be-7 as Observed During 9 years at USP71 \& USP76}

Both stations in Alaska, USP71 and USP76, receive large amount of rain and snow what has a direct influence on the surface measurements of Be-7. Figure 9a, b demonstrate significant month-to-month and station-to-station variations in the monthly values of Be-7. At the station USP71 the maximum monthly average value of $\mathrm{Be}-7$ is in March with its 9-year average equal to $3600 \pm 2457 \mu \mathrm{Bq} / \mathrm{m}^{3}$; the minimum monthly average value is in July, equal to $848 \pm 700$ $\mu \mathrm{Bq} / \mathrm{m}^{3}$. 

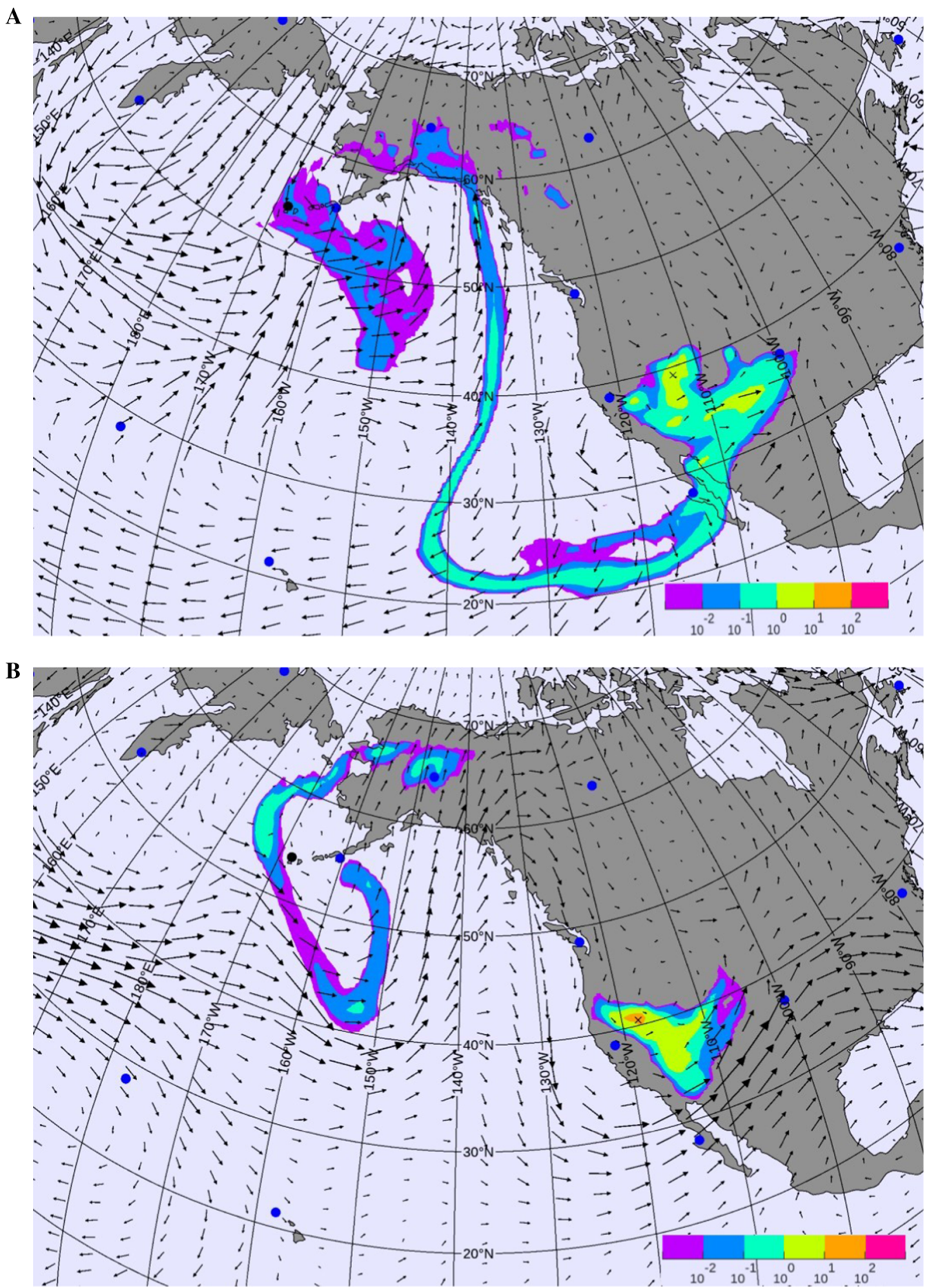

Figure 6

Snapshots showing the plume associated with a volcanic ash released from Bogoslof (black dot) on 20 January 2017. a Snapshot on 24 January at 9 pm UTC showing the plume arriving at the surface level (0-150 m) at USP71 and USP76. b Snapshot on 24 January 2017 at 12 am UTC showing the plume between 4 and $6 \mathrm{~km}$ passing over USP76 and approaching USP71. Blue dots indicate the location of IMS stations; the black arrows indicate wind directions: $\mathbf{a}$ at the surface and $\mathbf{b}$ at $526 \mathrm{hPa}$ (i.e. about $5196 \mathrm{~m}$ ). Please note that the colour scale refers to relative concentration values 
At the station USP76, the maximum monthly average value of $\mathrm{Be}-7$ is in May with its 9-year average equal to $4750 \pm 3056 \mu \mathrm{Bq} / \mathrm{m}^{3}$; monthly minimum is in November, equal to $1699 \pm 1151$. It coincides with a monthly distribution of total precipitation, both rain and snow. As Fig. 9c reveals, the highest amount of precipitation is in November and the lowest in May.

It should be noted that during the months considered in this study, December-February (DJF), the monthly values are in the same range, with the median value calculated for the period of 9 years equal to $1938 \mu \mathrm{Bq} / \mathrm{m}^{3}$ for USP71 and $2015 \mu \mathrm{Bq} / \mathrm{m}^{3}$ for USP76. These values will be used in the next section as a reference while studying the daily changes related to the volcanic ash.

\subsection{Influence of Volcanic Ash on Changes in Be-7 Activity Concentrations at 2 RN IMS Stations}

It has been demonstrated by KuśmierczykMichulec and Bourgouin (2018) that an influx of aerosol particles like dust at high levels $(3-10 \mathrm{~km})$ tends to locally increase surface Be-7 concentrations in area under the influence of subsiding dust plume. This effect is related to the altitude dependency of Be-7 concentrations (e.g. Kownacka, 2002). Furthermore, it has been shown that an influx of dust at lower altitudes (up to $1 \mathrm{~km}$ ) would have the opposite effect on surface concentrations. In case dust has been present in the whole column of atmosphere, its final impact depended on the ratio between its amount in the upper layers $(3-10 \mathrm{~km})$ and lower layers (0-1 km).

This study will demonstrate that a similar mechanism can be observed also for other aerosol particles like volcanic ash. Taking into account the complexity of winter ABL of Alaska, the definition of lower and upper layers was adapted accordingly. To reflect the fact that most of SBIs are in the layer between 0 and $500 \mathrm{~m}$, and the EIs are above $1200 \mathrm{~m}$ (see Sect. 4.1), the lower and upper layers were defined to be: 0-500 $\mathrm{m}$ and 1500-12,000 m, respectively.

The following sections discuss the influence of volcanic ash present in the upper layers (above $1.5 \mathrm{~km}$ ) on the surface Be-7 values measured at two IMS stations USP71 and USP76 during the three episodes. In each case, the analysed time period is slightly extended to take into account the fact that the increase of Be-7 is not immediate; it may take up to several days, depending on factors like for example amount of precipitation or amount of volcanic ash in the lower layer (below $0.5 \mathrm{~km}$ ).

It should be noted that since the amount of volcanic ash released during each episode is unknown, the constant value was assumed and the volcanic ash concentration at the station is given in relative units, which does not prevent from making direct comparisons between stations.

Figure 10a-f illustrates the passage of volcanic ash plume over USP71 and USP76 associated with the three episodes discussed in this study (i.e. from 19 to 31 December 2016, 20 January to 3 February 2017, and 17 February to 8 March 2017). It should be noted that in contrast to Fig. 5a-f, which shows the chronological evolution of the plume associated with a volcanic ash release at the time of the event, Fig. 10a-f displays the plume associated with daily volcanic ash releases for the whole duration of the episode.

Figures 11, 12 and 13 show daily variations in $\mathrm{Be}-7$ values along with the daily amount of volcanic ash for the upper layers $(1.5-12 \mathrm{~km})$ and lower layers $(0-0.5 \mathrm{~km})$. For reference, the seasonal median calculated for the period of 9 years (2009-2017) is plotted as dashed line (black). The yellow bars indicate the periods of low pressure during which either light rain or light snow were observed.

\subsubsection{Event 1: 19 December 2016}

Figures 10a and 11a reveal that the largest concentration of volcanic ash at the upper layers is observed at USP71 during the first few days counting from the release day, i.e. between 20 and 27 of December. Since 29 of December a slow increase in Be-7 values above the seasonal median is observed, slightly modified by the presence of volcanic ash in the lower layers. The maximum increase is between 7 and 12 January 2017 and Be-7 surface values reached the value of $12931\left[\mu \mathrm{Bq} / \mathrm{m}^{3}\right]$, exceeding more than 6 times the seasonal median. The presence of light snow between 12 and 16 January leads to a significant reduction in the amount of $\mathrm{Be}-7$ at the surface. 

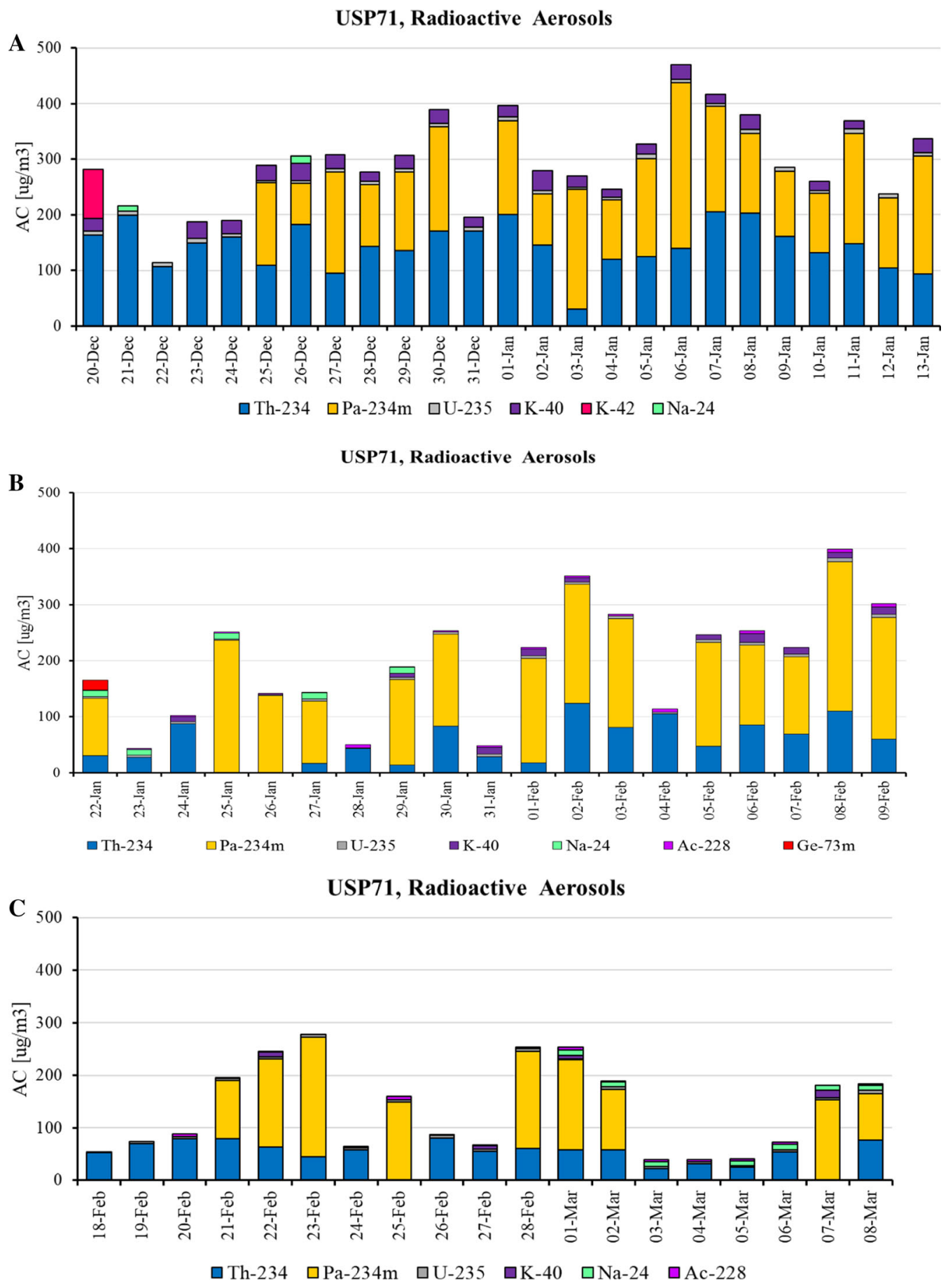

Figure 7

a-c Radioactive aerosols measured at USP71during the events associated with the volcanic eruption 


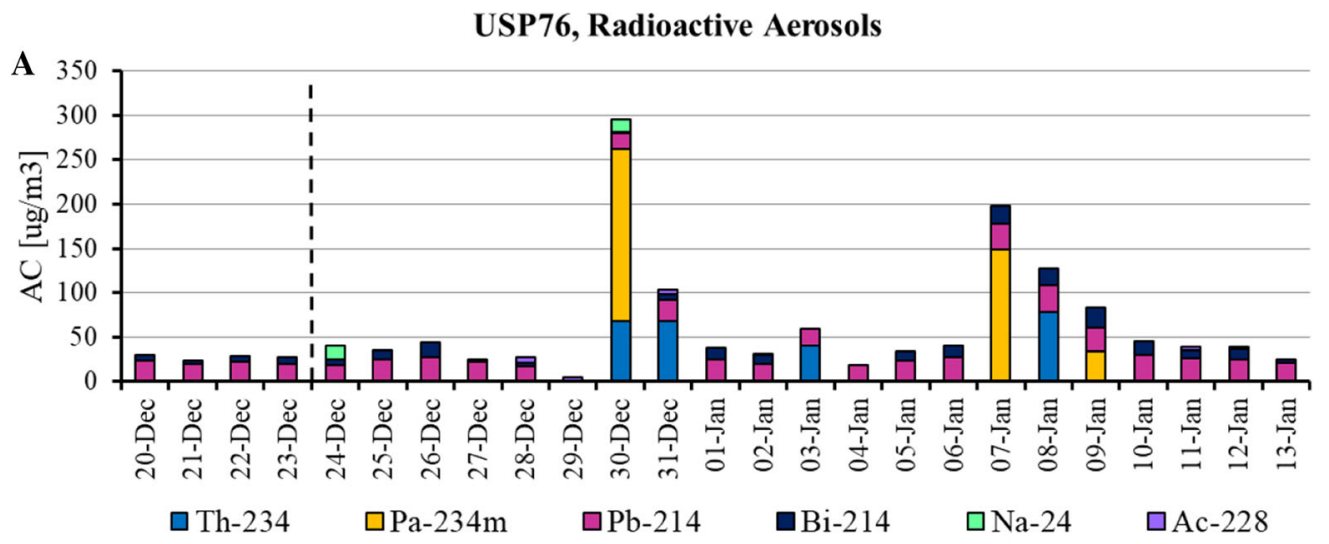

B

USP76, Radioactive Aerosols

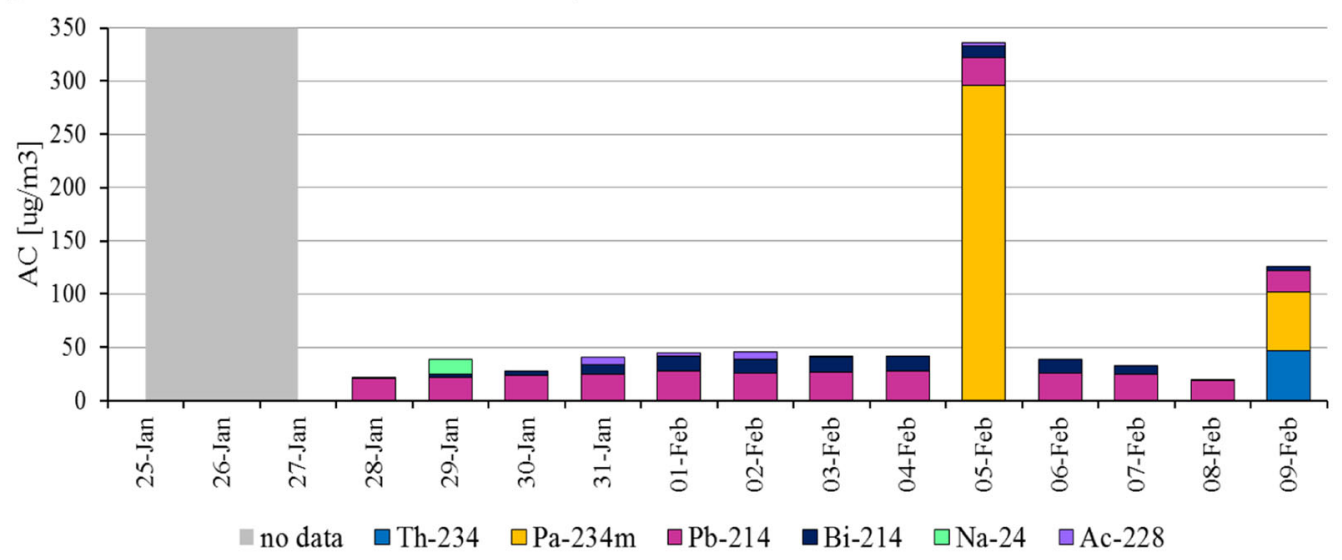

C

USP76, Radioactive Aerosols

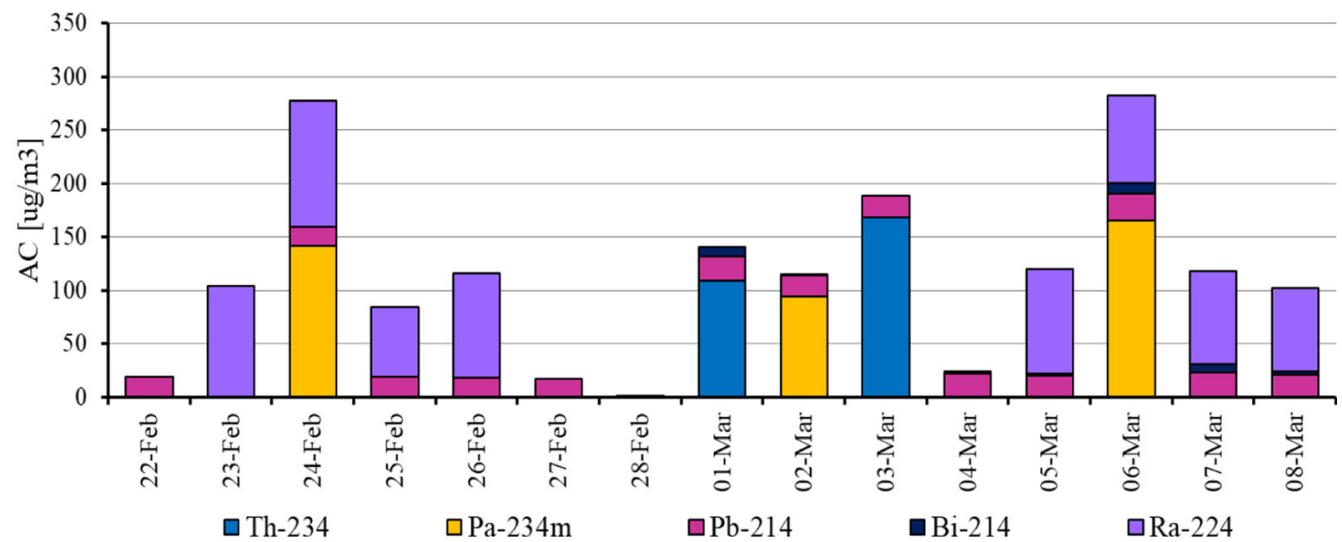

Figure 8

a-c Radioactive aerosols measured at USP76 during the events associated with the volcanic eruption. The dashed line in (a) marks the arrival of the ash plume at the surface. The grey bar in (b) marks the period with no data 

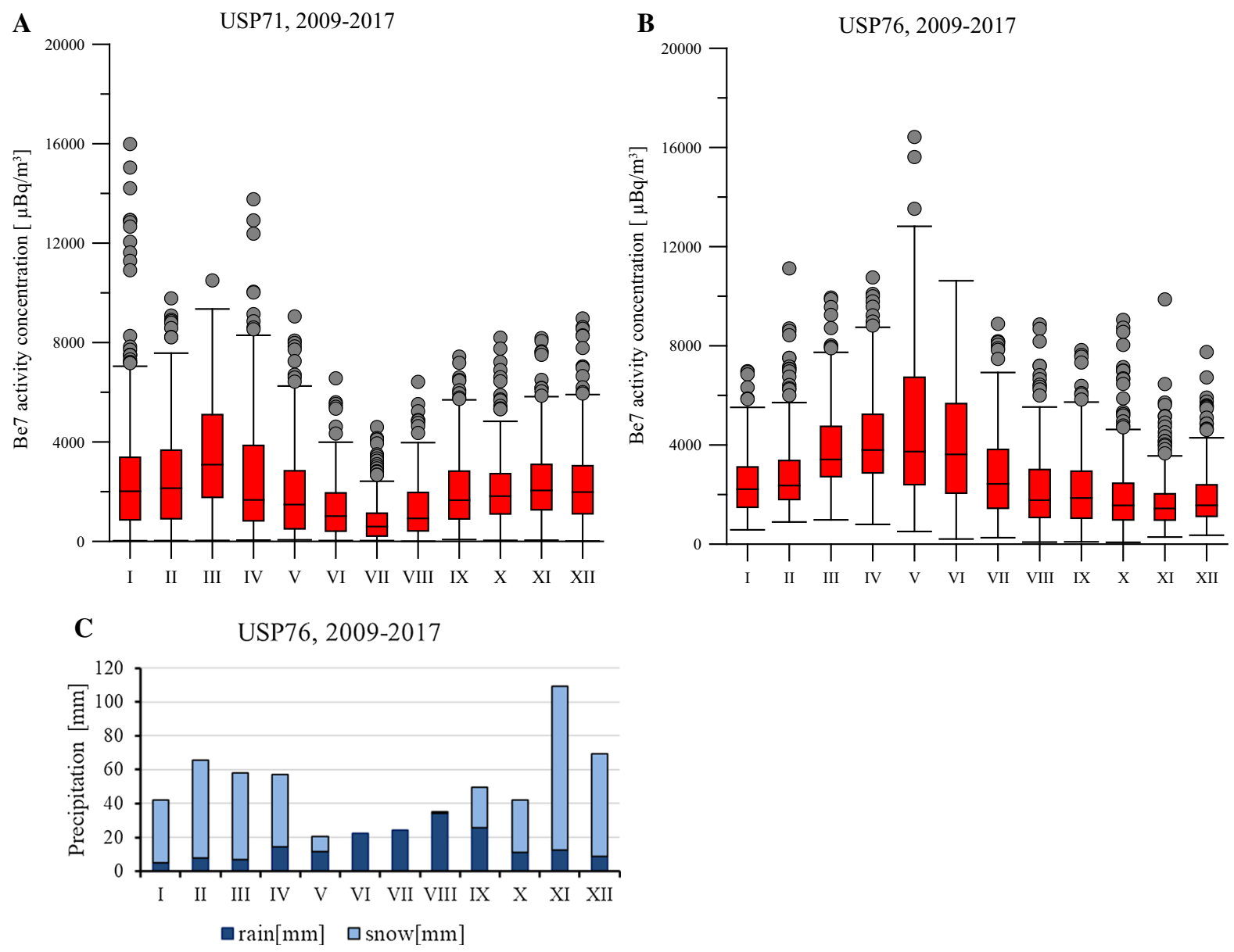

Figure 9

a, b Monthly distribution of Be-7 calculated for the period of 9 years: 2009-2017. Boxplot with whiskers from minimum to maximum, as observed at two IMS stations: USP71 and USP76. The upper and the lower edge of the box represent the First and the Third Quartile, respectively. The grey dots indicate outliers. c Average monthly precipitation (snow and rain) as observed at USP76

In case of USP76 the increase of Be-7 values is less pronounced. Two maxima observed on 4 and 12 January exceeded two times the seasonal median. On one hand, the amount of volcanic ash reaching the station USP76 is much smaller than in case of USP71, and thus the expected effect would be weaker, on the other hand the frequent periods of light snow, as shown in Fig. 11b, lead to removal of Be-7 particles from the atmosphere.

\subsubsection{Event 2: 20 January 2017}

The mechanism leading to the significant increase in Be-7 activity concentration was very similar to the previous case. As illustrated in Figs. 10c and 12a, the largest amount of volcanic ash in the upper layers were present during the first days from the release, i.e. between 24 and 29 January. The indirect effect of ash is demonstrated (Fig. 12a) by a significant increase in $\mathrm{Be}-7$ in the period between 4 and 8 February, with a maximum on 6 February when Be-7 activity concentration reached $9777\left[\mu \mathrm{Bq} / \mathrm{m}^{3}\right]$, exceeding 5 times the seasonal median. This increase was less pronounced than during the first event. Probably the frequent periods of light snow and light rain as well as the fact that the air mass trajectories were quite complex and it took some time until the ash plume reached the station, had an influence. 

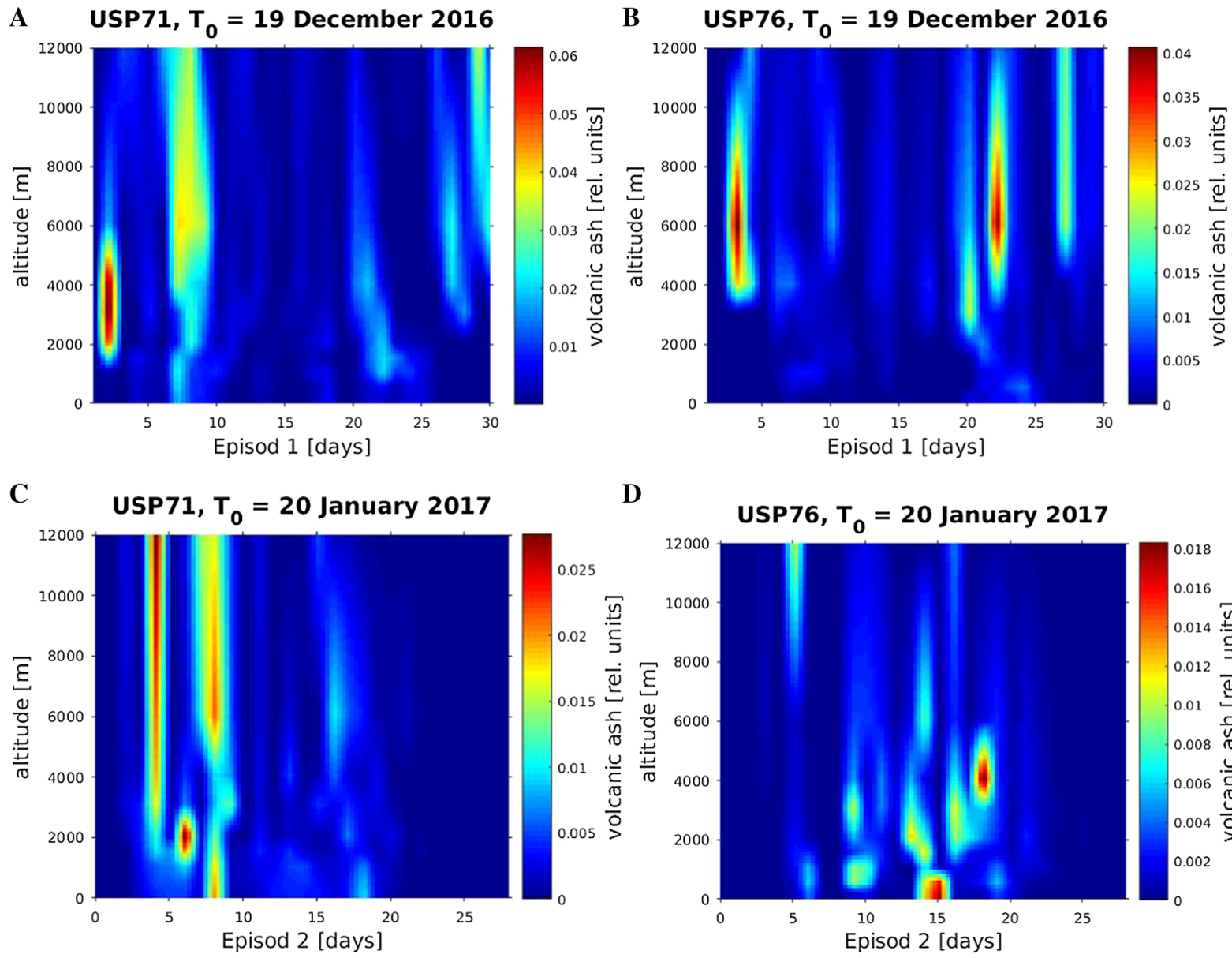

D
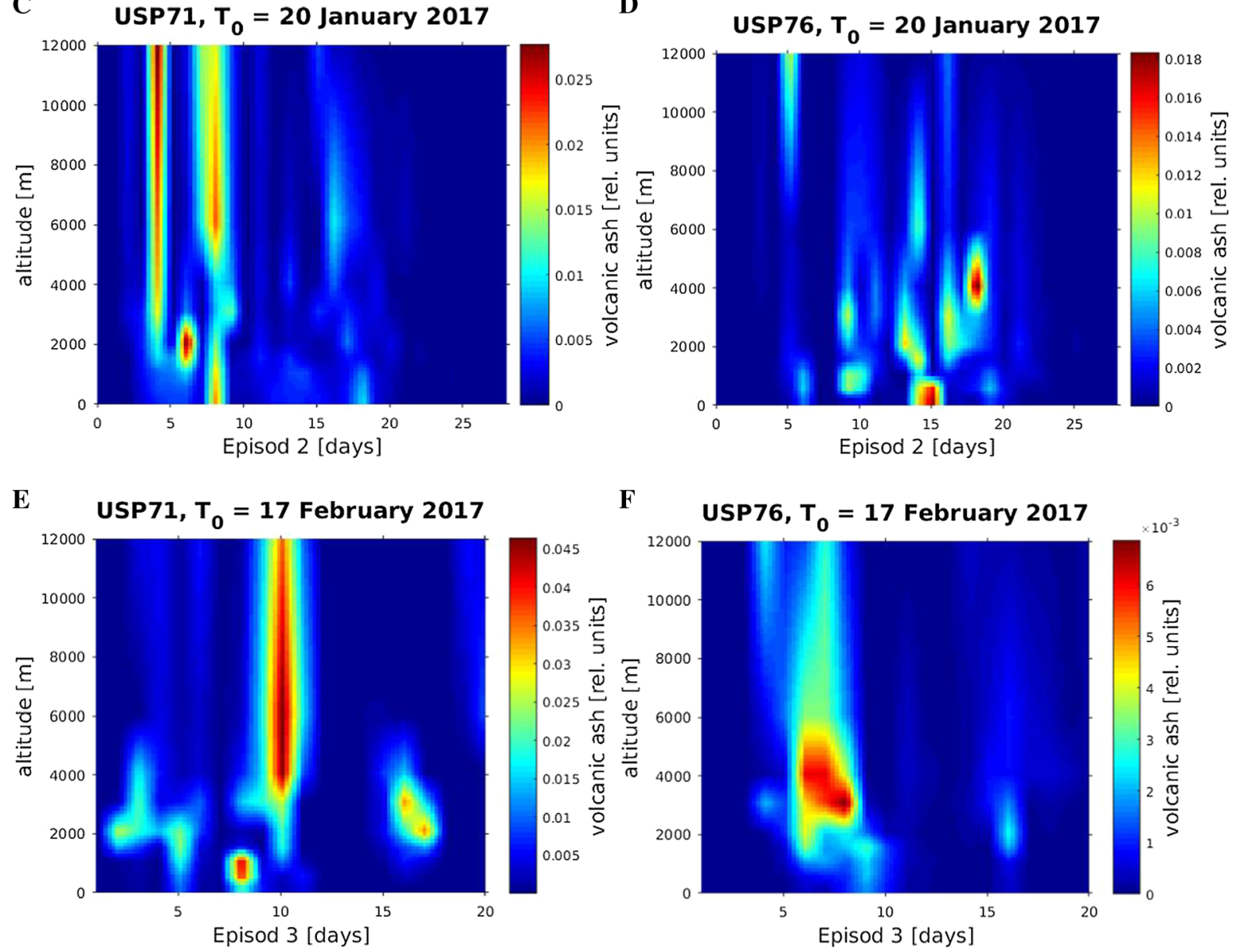

Figure 10

a-f The passage of the volcanic ash plume over USP71 and USP76 associated with daily volcanic ash releases for the whole duration of the episodes i.e. from 19 to 31 December 2016 (a, b), 20 January to 3 February 2017 (c, d), and 17 February to 8 March 2017 (e, f)

The increase in Be-7 activity concentration to $5059\left[\mu \mathrm{Bq} / \mathrm{m}^{3}\right]$, i.e. 2.5 times more than the seasonal median, can be observed at the station USP76
(Fig. 12b). However, presence of the multiple ash plumes in the upper layer (Fig. 10d) makes the scenario more complex. In this case the period during 
A

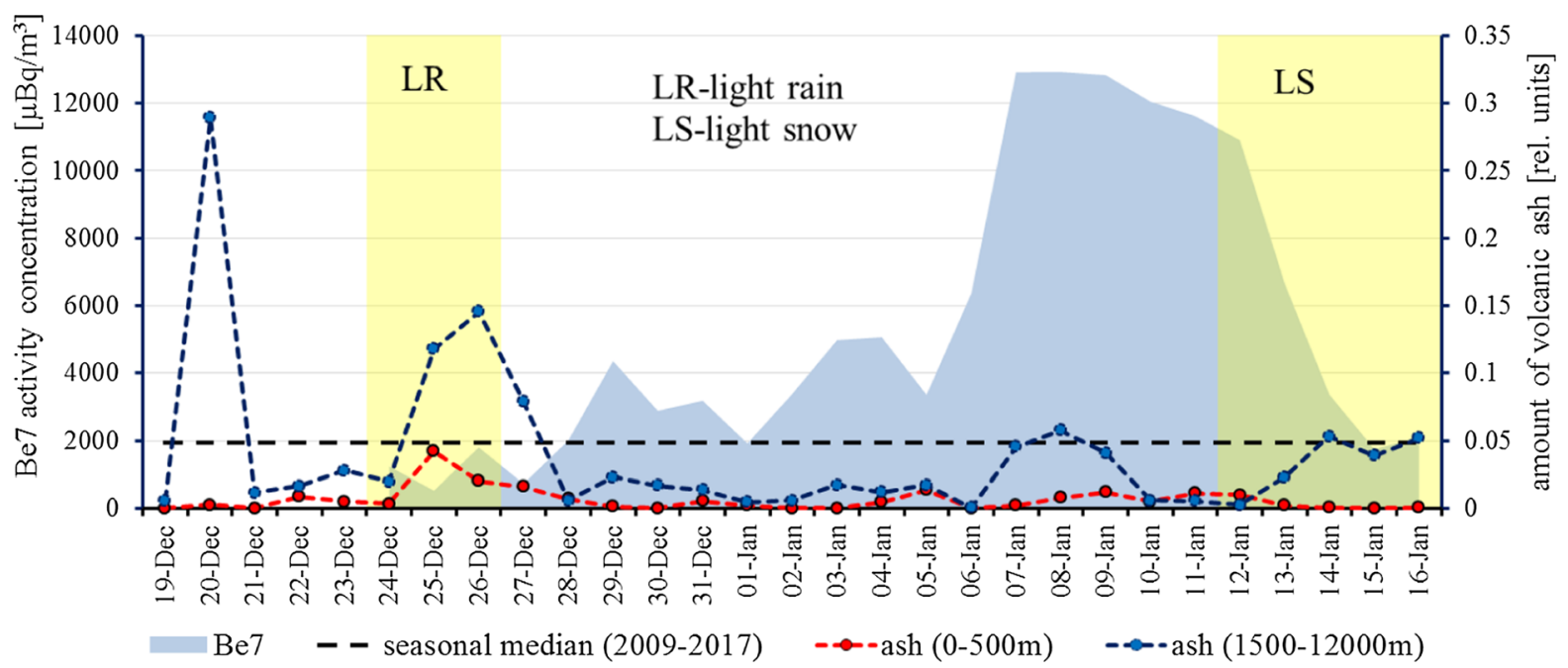

B

\section{USP76}

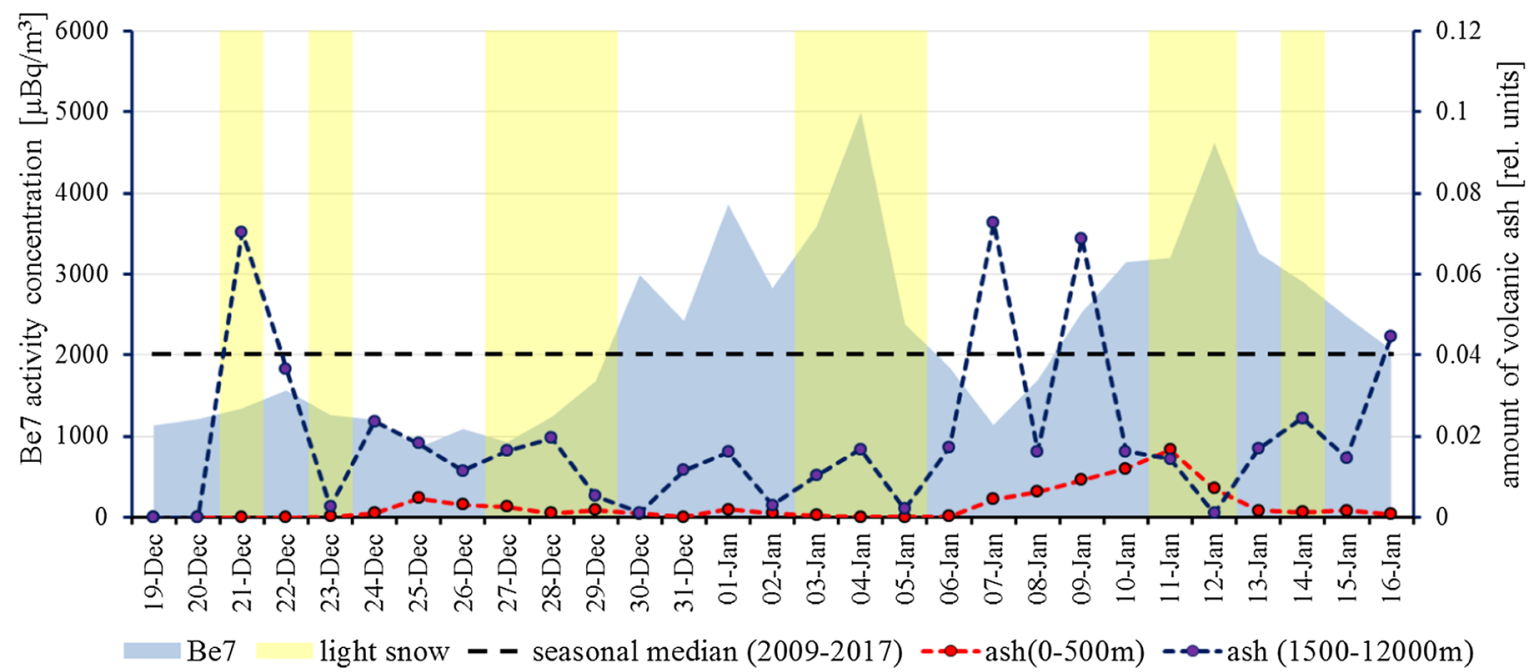

Figure 11

Daily variations in Be-7 values observed between 19 December 2016 and 16 January 2017 (episode 1) for two IMS stations: a USP71 and b USP76. For reference, the seasonal median is plotted as dashed line (black). Daily amount of volcanic ash for the upper layers (1.5-12 km) and lower layers $(0-0.5 \mathrm{~km})$ are plotted as well. The yellow bars indicate the periods of low pressure during which either light rain or light snow were observed

which ash plume was present in the upper layers was extended over several days. On the other hand, the relative amount of volcanic ash that reached USP76 was about two times smaller than at USP71.

\subsubsection{Event 3: 17 February 2017}

Figures 10e-f and 13a, b illustrate the relation between the presence of volcanic ash and the values of Be-7 measured at the surface at two IMS stations USP71 and USP76. Similarly to two previous cases, the significant increase in Be-7 values is preceded by the inflow of volcanic ash at higher altitudes. This increase depends on other factors like precipitation, and the amount of volcanic ash in the upper and lower layers. 
A

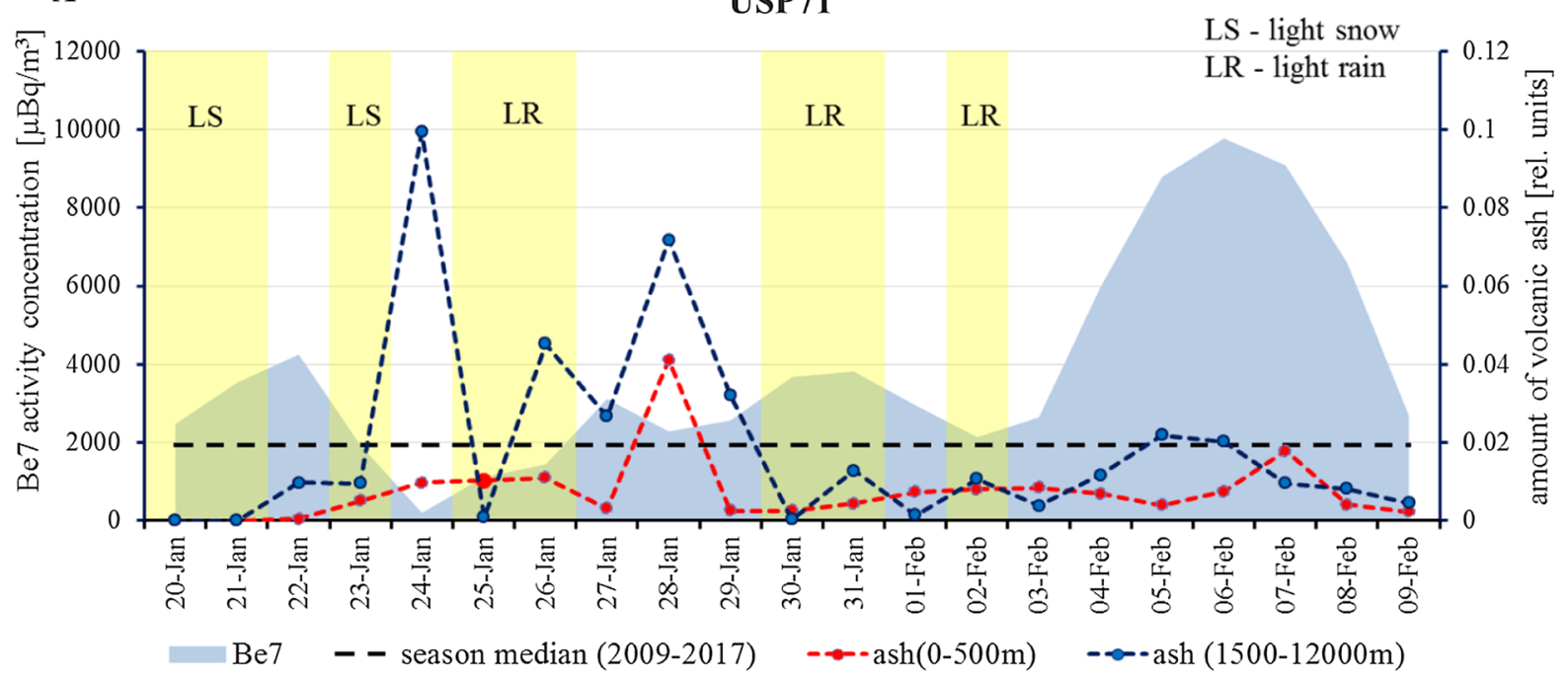

B

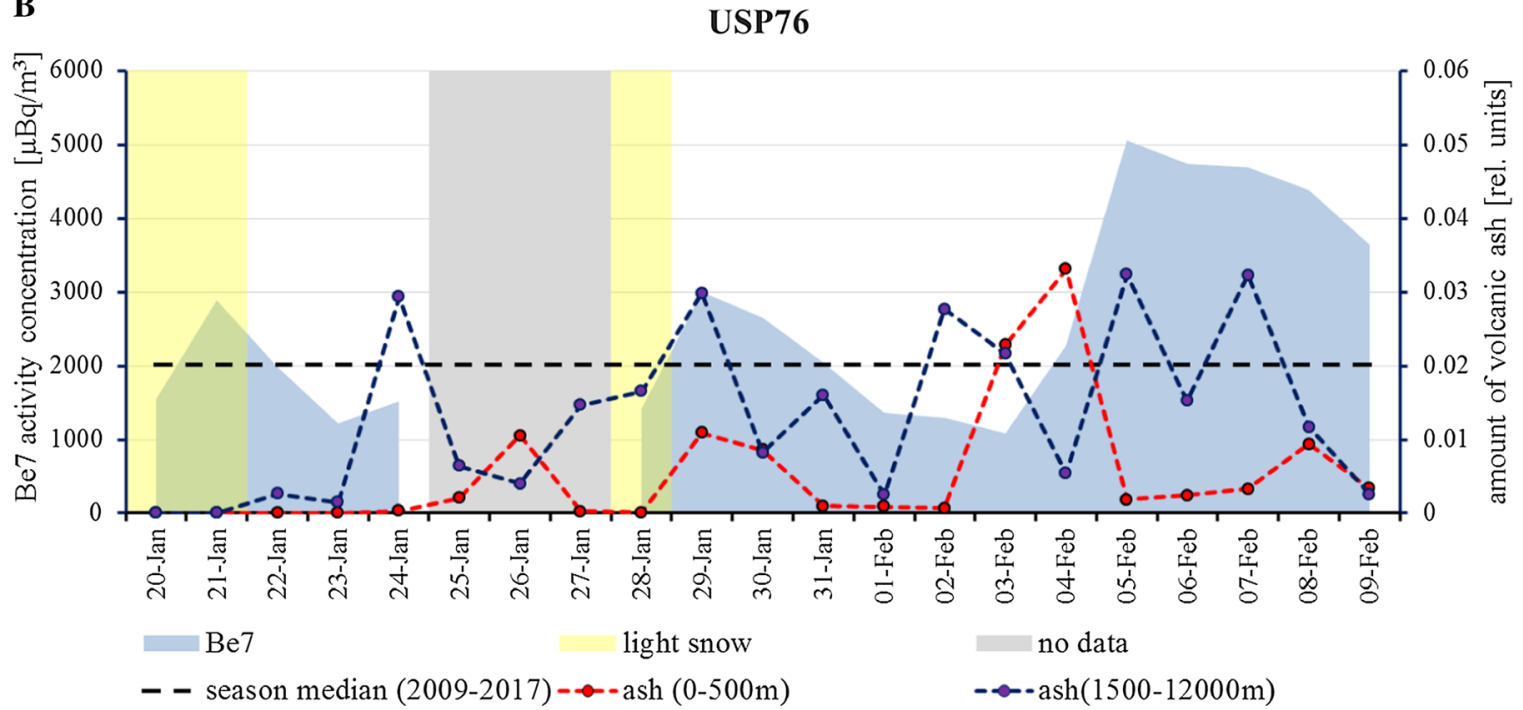

Figure 12

Daily variations in Be-7 values observed between 20 January and 9 February 2017 (episode 2) for two IMS stations: a USP71 and b USP76. For reference, the seasonal median is plotted as dashed line (black). Daily amount of volcanic ash for the upper layers (1.5-12 km) and lower layers $(0-0.5 \mathrm{~km})$ are plotted as well. The yellow bars indicate the periods of low pressure during which either light rain or light snow were observed. The grey bar (b) marks the period with no data

\section{Conclusions}

The recent Bogoslof volcanic eruptive sequence is used to demonstrate synergy between radionuclide, infrasound and ATM technologies. The principal conclusions related to this study are:
- The synergy of two verification technologies jointly with ATM allows overcoming limitations related to a single technology, and in particular the source ambiguity. The synergy provides a more complete picture of the Bogoslof eruptive sequence and its consequences with propagation of gases in the atmosphere. The infrasound observations are used to locate the explosive eruptions in space and 
A

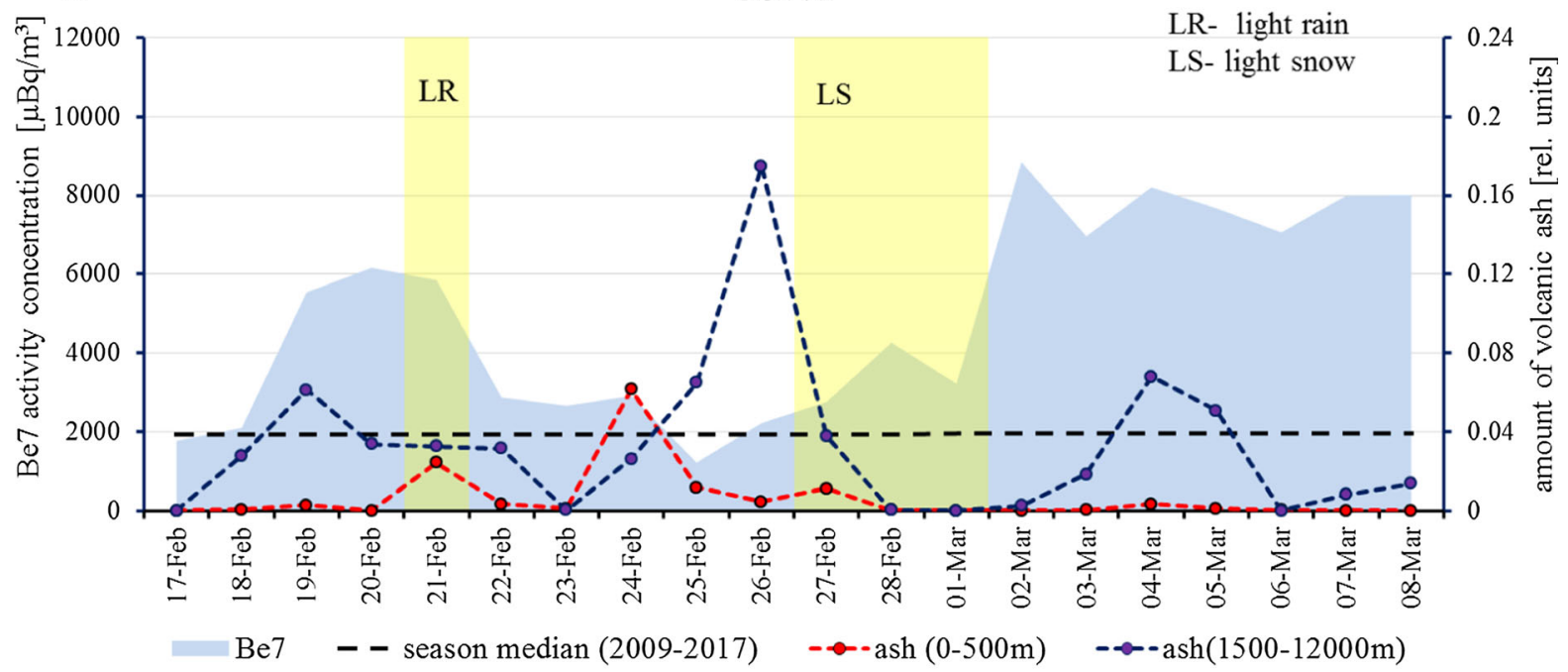

B

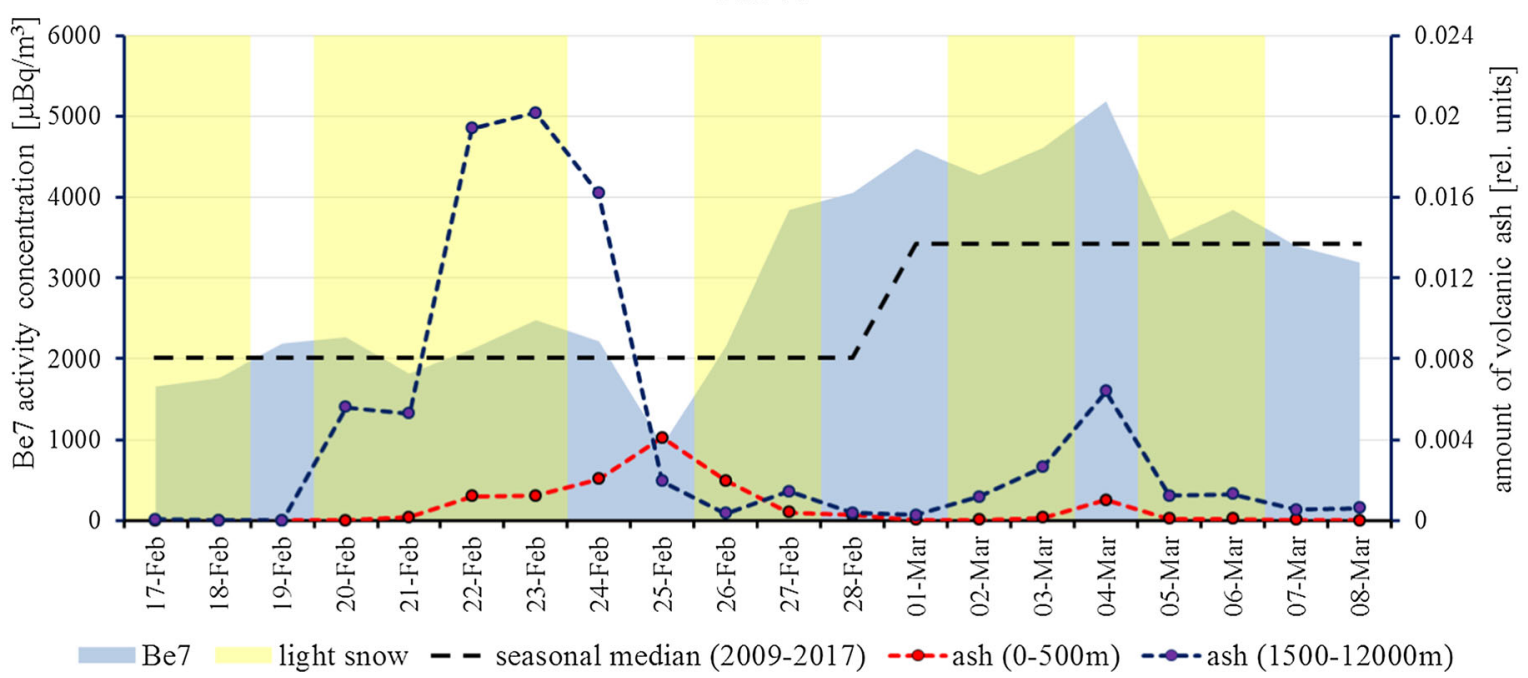

Figure 13

Daily variations in Be-7 values observed between 17 February and 8 March 2017 (episode 3) for two IMS stations: a USP71 and b USP76. For reference, the seasonal median is plotted as dashed line (black). Daily amount of volcanic ash for the upper layers (1.5-12 km) and lower layers $(0-0.5 \mathrm{~km})$ are plotted as well. The yellow bars indicate the periods of low pressure during which either light rain or light snow were observed

time; the ATM results allow investigating the air mass trajectories and provide a link between the event location derived from IMS infrasound observations and the radionuclide observations at the IMS stations. The latter ones give insight information related to the possible content of volcanic ash in terms of radioactive particles.

- It is demonstrated that an inflow of volcanic ash up to the tropopause tends to locally increase the surface values of Be-7. A similar mechanism was previously described in relation to dust particles and this study confirms that it is also valid for volcanic ash particles.

- The increase in Be-7 surface measurements exceeding 2.5 times the seasonal median can be considered as an indication of a possible inflow of aerosol particles up to tropopause taking place a few days earlier. As it was demonstrated in this 
study, this increase can exceed even 5 times the seasonal median. In case there is snow or rain leading to wash out, an increase will be less significant.

- Advanced and validated ATM driven by high quality meteorological fields represents a powerful tool to explore dispersion of different atmospheric constituents.

The usefulness of IMS infrasound data for monitoring explosive eruptions of volcanoes has been widely covered from near-field to far-field recordings (Johnson and Ripepe 2011). In this study however, the synergy and benefit of combining IMS data and IDC products from various technologies offers interesting perspectives for monitoring volcanic activity as well as a case study for fusion of technologies used by the CTBTO. The use of the synergy open the path to increased monitoring capabilities and possibly a way towards a quantitative description of the eruptive source.

The study performed for the recent Bogoslof activity should be repeated for other eruptive sequences to validate the finding. An open question remains when multiple active volcanoes present explosive eruptive sequence in the same geographical region and during a similar timeframe.

\section{Acknowledgements}

We acknowledge all CTBTO colleagues who contributed to IMS monitoring system and IDC analysis.

Open Access This article is licensed under a Creative Commons Attribution 4.0 International License, which permits use, sharing, adaptation, distribution and reproduction in any medium or format, as long as you give appropriate credit to the original author(s) and the source, provide a link to the Creative Commons licence, and indicate if changes were made. The images or other third party material in this article are included in the article's Creative Commons licence, unless indicated otherwise in a credit line to the material. If material is not included in the article's Creative Commons licence and your intended use is not permitted by statutory regulation or exceeds the permitted use, you will need to obtain permission directly from the copyright holder. To view a copy of this licence, visit http://creativecommons.org/licenses/by/4. $0 /$.

\section{Data Availability}

Meteorological data were provided by the European Centre for Medium-Range Weather Forecasts under a collaboration agreement with the CTBTO. Data which are not owned by PTS were obtained online with data links mentioned in the data set section.

\section{Appendix 1}

Acronym list

AC Activity Concentration

ATM Atmospheric Transport Modelling

ARR Automated Radionuclide Reportrequested for Particulate Stations provide results from the automated analysis of a particulate sample

CTBTO Comprehensive Nuclear-Test-Ban Treaty Organization

ECMWF European Centre for Medium-Range Weather Forecasts

GNU A free Unix-like operating system, its name means "GNU's Not Unix"

IDC International Data Centre

IMS International Monitoring System

MDC Minimum Detectable Concentration

PMCC Progressive Multi Channel Correlation

PTS Provisional Technical Secretariat

REB Reviewed Event Bulletin

RN Radionuclide

RRR Reviewed Radionuclide Report-revised version of the ARR and is generated after the manual analysis of a particulate or gas sample is complete

SRS Source-receptor sensitivity

Publisher's Note Springer Nature remains neutral with regard to jurisdictional claims in published maps and institutional affiliations. 


\section{REFERENCES}

Benioff, P. A. (1956). Cosmic-ray production rate and mean removal time of beryllium-7 from the atmosphere. Physical Review, 104(4), 1122-1130.

Brattich, E., Orza, J. A. G., Cristofanelli, P., Bonasoni, P., \& Tositti, L. (2017). Influence of stratospheric air masses on radiotracers and ozone over the central Mediterranean. Journal of Geophysical Research, 122(13), 7164-7182.

Brown, D. J., Katz, C. N., Le Bras, R., Flanagan, M. P., Wang, J., \& Gault, A. K. (2002). Infrasonic signal detection and source location at the Prototype Data Centre. Pure and Applied Geophysics, 159, 1081-1125. https://doi.org/10.1007/s00024-0028674-2.

Byers, F. M. Jr. (1959). Geology of Umnak and Bogoslof Islands, Aleutian Islands, Alaska. U. S. Geological Survey Bulletin 1028-L, pp. 267-369. http://dggs.alaska.gov/webpubs/usgs/b/ text/b10281.pdf. Accessed 12 June 2020.

Coombs, M. L., Wech, A. G., Haney, M. M., Lyons, J. J., Schneider, D. J., Schwaiger, H. F., et al. (2018). Short-term forecasting and detection of explosions during the 2016-2017 Eruption of Bogoslof Volcano, Alaska. Frontiers in Earth Science, 6, 122. https://doi.org/10.3389/feart.2018.00122.

CTBTO. (2018). Verification Regime. Online (https://www.ctbto. org/verification-regime/).

D’Amours, R., Mintz, R., Mooney, C., \& Wiens, B. J. (2013). A modeling assessment of the origin of Beryllium-7 and Ozone in the Canadian Rocky Mountains. Journal of Geophysics Research, 118(10), 10125-10138. https://doi.org/10.1002/jgrd. 50761.

Fee, D., \& Matoza, R. S. (2013). An overview of volcano infrasound: from hawaiian to plinian, local to global. Journal of Volcanology and Geothermal Research, 249, 123-139.

Gauthier, P. J., Le Cloarec, M. F., \& Condomines, M. (2000). Degassing processes at Stromboli volcano inferred from shortlived disequilibria $(210 \mathrm{~Pb}-210 \mathrm{Bi}-210 \mathrm{Po})$ in volcanic gases. Journal of Volcanology and Geothermal Research, 102, 1-19.

Global Volcanism Program. (2013). Bogoslof (311300) in Volcanoes of the World, v. 4.8.3. In E. Venzke (Ed.), Smithsonian Institution, Downloaded 23 Sep 2019 (https://volcano.si.edu/ volcano.cfm? vn=311300). https://doi.org/10.5479/si.GVP. VOTW4-2013

Global Volcanism Program. (2017). Report on Bogoslof (United States). In A. E. Crafford \& E. Venzke (Eds.), Bulletin of the Global Volcanism Network, 42:12. Smithsonian Institution. https://doi.org/10.5479/si.GVP.BGVN201712-311300. Accessed 18 Feb 2019.

Ioannidou, A., Manolopoulou, M., \& Papastefanou, C. (2005). Temporal changes of $\mathrm{Be}-7$ and $\mathrm{Pb}-210$ concentrations in surface air at temperate latitudes $\left(40^{\circ} \mathrm{N}\right)$. Applied Radiation and Isotopes, 63, 277-284.

Johnson, J. B., \& Ripepe, M. (2011). Volcano infrasound: A review. Journal of Volcanology and Geothermal Research, 206(3), 61-69.

Kownacka, L. (2002). Vertical distributions of beryllium-7 and lead-210 in the tropospheric and lower stratospheric air. Nukleonika, 47(2), 79-82.

Kuśmierczyk-Michulec, J., \& Bourgouin, P. (2018). Influence of mineral dust on changes of Be-7 concentrations in air as measured by CTBTO global monitoring system. Journal of
Environmental Radioactivity, 192, 454-466. https://doi.org/10. 1016/j.jenvrad.2018.07.015.

Kuśmierczyk-Michulec, J., Gheddou, A., \& Nikkinen, M. (2015). Influence of precipitation on Be-7 concentrations in air as measured by CTBTO global monitoring system. Journal of Environmental Environmental Radioactivity, 144, 140-151. https://doi.org/10.1016/j.jenvrad.2015.03.014.

Lal, D., \& Peters, B. (1967). Cosmic ray produced radioactivity on the Earth. Handbook of Physics, 46, 551-612.

Lambert, G., Le Cloarec, M. F., Ardouin, B., \& Le Roulley, J. C. (1985). Volcanic emission of radionuclides and magma dynamics. Earth and Planetary Science Letters, 76, 185-192.

Lange, C. (1994). Size distribution of atmospheric particles containing beryllium-7. Journal of Aerosol Science, 25, 45.

Malingowski, J., Atkinson, D., Fochesatto, J., Cherry, J., \& Stevens, E. (2014). An observational study of radiation temperature inversions in Fairbanks, Alaska. Polar Science, 8, 24-39. https:// doi.org/10.1016/j.polar.2014.01.002.

Masarik, J., \& Beer, J. (1999). Simulation of particle fluxes and cosmogenic nuclides production in the earth's atmosphere. Journal of Geophysical Research, 104, 12099-12112.

Mastin, L. G., Guffanti, M., Servranckx, R., Webley, P., Barsotti, S., Dean, K., et al. (2009). A multidisciplinary effort to assign realistic source parameters to models of volcanic ash-cloud transport and dispersion during eruptions. Journal of Volcanology and Geothermal Research, 186(1), 10-21. https://doi.org/10. 1016/j.jvolgeores.2009.01.008.

Matoza, R. S., Fee, D., Green, D., \& Mialle, P. (2019). Volcano infrasound and the International Monitoring System. https:// www.springer.com/gp/book/9783319751382\#. Accessed 2 Jan 2019.

Mayfield, J. A., \& Fochesatto, G. J. (2013). The layered structure of the winter atmospheric boundary layer in the interior of Alaska. Journal of Applied Meteorology and Climatology, 52, 953-973. https://doi.org/10.1175/JAMC-D-12-01.1.

Medici, F. (2001). The IMS radionuclide network of the CTBT. Radiation Physics and Chemistry, 161, 689-690.

Merriam, C. H. (1902). Bogoslof, our newest volcano (Vol. 2, pp. 291-336). New York: Harriman Alaska Expedition.

Mialle, P., Brown, D., Arora, N., \& colleagues from IDC. (2019). Advances in operational processing at the international data centre. In A. Le Pichon, E. Blanc, \& A. Hauchecorne (Eds.), Infrasound monitoring for atmospheric studies. Cham: Springer.

NOAA. (2017). National Centers for Environmental Information, State of the Climate: Synoptic Discussion for January 2017. https://www.ncdc.noaa.gov/sotc/synoptic/201701. Accessed 3 Aug 2019.

Oversby, V. M., \& Gast, P. W. (1968). Lead isotope compositions and uranium decay series disequilibrium in recent volcanic rocks. Earth and Planetary Science Letters, 5, 348-349.

Rafiza, A. R., Bakri, A. M., Kamarudin, H., Nizar, I. K., Hardjito, D., Sandu, I., \& Yahya, Z. (2013). Study on radioactivity components, water quality and microstructure characteristic of volcano ash as geopolymer artificial aggregate (Doctoral dissertation, Petra Christian University).

Schulze, J., Auer, M., \& Werzi, R. (2000). Low level radioactivity measurement in support of the CTBTO. Applied Radiation and Isotopes, 53, 23-30.

Stohl, A., Forster, C., Frank, A., Seibert, P., \& Wotawa, C. G. (2005). Atmos. Chemical Physics, 5, 2461-2474. 
Terray, L., Gauthier, P. J., Salerno, G., Caltabiano, T., La Spina, A., Sellitto, P., et al. (2018). A new degassing model to infer magma dynamics from radioactive disequilibria in volcanic plumes. Geosciences, 8(1), 27.

Terzi, L., \& Kalinowski, M. (2017). World-wide seasonal variation of Be-7 related to large-scale atmospheric circulation dynamics. Journal of Environmental Radioactivity, 178-179, 1-15. https:// doi.org/10.1016/j.jenvrad.2017.06.031.

Usoskin, I. G., \& Kovaltsov, G. A. (2008). Production of cosmogenic Be-7 isotope in the atmosphere: Full 3-D modelling.
Journal of Geophysical Research, 113, D12107. https://doi.org/ 10.1029/2007JD009725.

Wotawa, G., et al. (2003). Atmospheric transport modelling in support of CTBT verification: Overview and basic concepts. Atmospheric Environment, 37(18), 2529-2537.

Zanis, P., Gerasopoulos, C., Priller, A., Schnabel, C., Zerefos, C., Gaggeler, H.W., et al. (2003). An estimate of the impact of stratosphere-to-troposphere transport (STT) on the lower free tropospheric ozone over the Alps using 10Be and 7Be measurements. Journal of Geophysical Research, 108(D12), 8520. https://doi.org/10.1029/2002JD002604.

(Received December 8, 2019, revised May 10, 2020, accepted May 12, 2020, Published online June 15, 2020) 